\author{
RafałŁatka \\ Biuro Badań Historycznych Instytutu Pamięci Narodowej \\ w Warszawie
}

\title{
Rada Główna Episkopatu Polski a pierwsza pielgrzymka Jana Pawła II do Ojczyzny w 1979 r.
}

\begin{abstract}
Abstrakt: Celem poniższej analizy jest opisanie stosunku Rady Głównej Episkopatu Polski do pierwszej pielgrzymki Jana Pawła II do Polski. Dostęp do dokumentacji kościelnej umożliwił odtworzenie podejścia członków tego kierowniczego gremium polskiego Kościoła do negocjacji związanych z wizytą Ojca Świętego, jej przebiegu i wreszcie efektów pielgrzymki.
\end{abstract}

Słowa kluczowe: Episkopat, Jan Paweł II, władze, Stefan Wyszyński.

Abstract: The purpose of the analysis presented below is to present the attitude of the Main Council of the Polish Episcopate towards Pope John Paul II's first pilgrimage to Poland. An access to Church archival documents made it possible to reconstruct individual attitudes of members of the Polish Church authorities towards negotiations related to the pope's visit, its course, and finally its outcomes.

Keyw ords: Episcopate, John Paul II, authorities, Stefan Wyszyński.

\section{Wprowadzenie}

Pierwsza wizyta Jana Pawła II w Ojczyźnie to niewątpliwie z wielu powodów wydarzenie o charakterze przełomowym w dziejach Polski. Zwracało na ten fakt uwagę wielu badaczy, szczególnie podkreślając jej kluczowe znaczenie dla odrodzenia podmiotowości społecznej ${ }^{1}$, a równocześnie dla delegitymizacji reżimu

\footnotetext{
${ }^{1}$ Na ten temat szerzej zob. A. Dudek, R. Gryz, Komuniści i Kościót w Polsce (1945-1989), Kraków 2006, s. 346-347; J. Żaryn, Jan Pawet II pogromca żelaznej kurtyny, w: Solidarność z błoń. Wokót nauczania społecznego Jana Pawła II, red. M. Drzonek, M. Siedziako, Szczecin
} 
i ekipy partyjnej kierowanej przez Edwarda Gierka². Na temat pielgrzymki Ojca Świętego w 1979 r. powstała już dość obszerna literatura, koncentrująca się głównie na jej efektach społecznych oraz przede wszystkim na działaniach władz wobec wizyty ${ }^{3}$. W swojej analizie chciałbym spojrzeć na przygotowania, przebieg oraz efekty przyjazdu Jana Pawła II do Ojczyzny przez pryzmat opinii Rady Głównej (RG) Episkopatu, czyli gremium decyzyjnego w polskim Kościele. Stało się to możliwe dzięki dostępowi do dokumentacji Sekretariatu

2011, s. 20-21; A. Nowak, Czas walki z Bogiem, seria: „Kościół na straży polskiej wolności”, t. IV, Kraków 2011, s. 152; R. Łatka, Stosunki państwo-Kościót w latach osiemdziesiatych na przyktadzie wizyt Jana Pawła II w Krakowie, w: Stosunki państwo-Kościót w Polsce 1944-2010. Studia i materiaty, red. R. Łatka, Kraków 2012, s. 96-97.

${ }^{2}$ Najtrafniej wyraził to Marcin Zaremba, który podkreślił: „Rozpoczęta 2 czerwca 1979 r. pielgrzymka Jana Pawła II miała wymiar religijny, ale i społeczny o rewolucyjnych konsekwencjach. W ciagu kilku miesięcy papież stał się narodowym autorytetem, ośrodkiem identyfikacji narodowej. Te uczucia uzewnętrzniły się również podczas jego wizyty [...]. Gdy spotkał się z Edwardem Gierkiem w Belwederze koncentrował na sobie wzrok. Był uśmiechnięty, jednocześnie pełen godności i skupienia. Mówił rzeczy ważne: o polskiej historii, rozumieniu słowa ojczyzna, wspólnocie losu narodu i Kościoła. Wskazując na prawo Polaków do życia w suwerennym państwie, przywracał sens słowom ojczyzna, prawda, wolność. [...] W tej konfrontacji I sekretarz KC PZPR wypadł słabo. Jego przemówienie niczym nie zaskakiwało, było sztampowe i banalne [...]. Gierek był lubiany i szanowany przez niemałą część Polaków. Gdy jednak stanął obok Jana Pawła II i przemówił, stracił cała swoją charyzmę, jego urok przepadł. W procesie delegitymizacji władzy - poprzedzającym każda rewolucję - było to wydarzenie ważne”. Cyt. za: M. Zaremba, Zimno, ciepło, goraco. Nastroje Polaków od „zimy stulecia” do lata 1980, w: Solidarność od wewnatrz 1980-1981, red. A. Friszke, K. Persak, P. Sowiński, Warszawa 2013, s. 21-22.

${ }^{3} \mathrm{Na}$ temat pierwszej pielgrzymki powstało już kilka samodzielnych, wartych uwagi opracowań historycznych: Wizyta Jana Pawła II w Polsce 1979. Dokumenty KC PZPR i MSW, oprac. A. Friszke, M. Zaremba, Warszawa 2005; M. Lasota, Zabezpieczenie pobytu Jana Pawła II w Polsce, w: Operacja: zniszczyć Kościót, red. F. Musiał, J. Szarek, Kraków 2007, s. 135-159; W.J. Skalski, Pierwsza pielgrzymka Ojca Świętego Jana Pawta II do Polski. Jan Pawet II w Nowym Targu - 8 czerwca 1979 r. - w dokumentach Stużby Bezpieczeństwa PRL, Kraków 2008; F. Musiał, Operacja „Lato-79”. Zadania Stużby Bezpieczeństwa w czasie pierwszej pielgrzymki Jana Pawła II do Polski, „Zeszyty Historyczne WiN-u” 2012, nr 35, s. 219-228. Problematyka ta pojawiała się również rzecz jasna w syntezach poświęconych relacjom państwo-Kościół w PRL: J. Żaryn, Dzieje Kościoła katolickiego w Polsce (19441989), Warszawa 2003, s. 405-414; A. Dudek, R. Gryz, op. cit., s. 341-347; Z. Zieliński, współudz. S. Bober, Kościót w Polsce 1944-2007, Poznań 2009, s. 201-207. Problematykę tej wizyty poruszałem również w kilku własnych publikacjach: Stosunki państwo-Kościót w latach osiemdziesiatych..., s. 93-105; Pielgrzymki Jana Pawta II do Krakowa w oczach SB. Wybór dokumentów, oprac. R. Łatka, Kraków 2013, s. 11-15, 33-73; Polityka władz Polski „ludowej” wobec Kościoła katolickiego w latach 1944-1979 (przypadek krakowski), „Zeszyty Historyczne WiN-u” 2014, nr 39, s. 184-187; Najważniejsi funkcjonariusze SB $w$ czasie wizyt papieskich $w$ Krakowie, w: Elity komunistyczne $w$ Polsce, red. M. Szumiło, M. Żukowski, Warszawa 2015, s. 420-421; Polityka władz PRL wobec Kościoła katolickiego $w$ województwie krakowskim w latach 1975-1980, w: PRL na pochylni 1975-1980, red. M. Bukała, D. Iwaneczko, Rzeszów 2017, s. 717-721. Warto sięgnaćc również po fragmenty popularnego opracowania Marka Lasoty, Donos na Wojtytę. Karol Wojtyła w teczkach bezpieki, Kraków 2006, s. 279-316. 
Prymasa Polski pochodzących ze zbiorów Archiwum Archidiecezji Warszawskiej ${ }^{4}$ Z Zasadniczy materiał, na którym będzie bazować moja analiza, stanowia protokoły RG z lat 1978-1979, wraz z załącznikami ${ }^{5}$. Jako ich uzupełnienie należy traktować inne dokumenty pochodzące z Sekretariatu Prymasa Polski $^{6}$, fragmenty dziennika „Pro memoria” prymasa Stefana Wyszyńskiego dokumenty dotyczące negocjacji Kościoła z władzami na temat wizyty i relacji państwo-Kościół ${ }^{8}$, relacje poszczególnych członków Rady wydane drukiem ${ }^{9}$ oraz istniejąca literature przedmiotu, która przywołano powyżej. Spojrzenie na tę problematykę przez pryzmat ciała kluczowego i decyzyjnego w polskim Kościele w istotny sposób uzupełni stan dotychczasowych badań o nowe wątki.

\section{Negocjacje związane z terminem przyjazdu Jana Pawła II}

Wybór konklawe, dokonany 16 X 1978 r., słusznie uznawany jest za jedno z najważniejszych wydarzeń w historii Polski. Miał on przełomowe znaczenie nie tylko dla polskiego społeczeństwa i Kościoła, ale również dla świata. Ważność

\footnotetext{
${ }^{4}$ Zgody na wykorzystanie tych dokumentów udzielił mi kard. Kazimierz Nycz, któremu w tym miejscu chciałbym złożyć za to serdeczne podziękowania.

${ }^{5}$ Archiwum Archidiecezji Warszawskiej, Sekretariat Prymasa Polski (dalej: AAW, SPP), 04/33-34, Protokoły Rady Głównej Episkopatu Polski 1978-1979.
}

${ }^{6}$ AAW, SPP, Kościół-Państwo, 25, Materiały z rozmowy z Edwardem Gierkiem, I sekretarzem KC PZPR, 24 I 1979; AAW, SPP, 04/119, Sekretarz Episkopatu; AAW, SPP, 04/295, Konferencja Plenarna Episkopatu Polski 27-28 XI 1978; AAW, SPP, 04/296, Konferencja Plenarna Episkopatu Polski 7-8 II 1979; AAW, SPP, 04/297, Konferencja Plenarna Episkopatu Polski z 21-22 III 1979; AAW, SPP, 04/298, Konferencja Plenarna Episkopatu Polski z 5-6 VI 1979; AAW, SPP, 04/299, Konferencja Plenarna Episkopatu Polski z 5-6 IX 1979.

7 Korzystałem z fragmentów cytowanych przez Petera Rainę i Ewę K. Czaczkowska. P. Raina, 1978. Wybór Papieża Jana Pawła II. Zapiski prymasa, Warszawa 2008; idem, Kardynat Wyszyński. Czasy prymasowskie 1978, Biała Podlaska-Warszawa 2010; idem, Kardynat Wyszyński. Czasy Prymasowskie 1979, Biała Podlaska-Warszawa 2010; E.K. Czaczkowska, Kardynat Wyszyński. Biografia, Kraków 2013.

${ }^{8}$ P. Raina, Arcybiskup Dabrowski w stużbie Kościoła i Narodu. Rozmowy z władzami PRL, t. I: 1970-1981, Warszawa 1995; Kościót w PRL. Kościót katolicki a państwo w świetle dokumentów 1945-1989, t. III: Lata 1975-1989, oprac. P. Raina, Poznań-Pelplin 1996; P. Raina, Wizyty apostolskie Jana Pawta II w Polsce. Rozmowy przygotowawcze Watykan-PRL-Episkopat, Warszawa 1997; idem, Arcybiskup Dabrowski - rozmowy watykańskie, Warszawa 2001; Wizyta Jana Pawta II...; W.J. Skalski, op. cit.; Pielgrzymki Jana Pawta II..., s. 11-73.

${ }^{9}$ Człowiek niezwyktej miary. Ojciec Święty Jan Pawet II o kardynale Stefanie Wyszyńskim. Kardynat Stefan Wyszyński o sobie. Kardynat Józef Glemp o kardynale Stefanie Wyszyńskim, red. M. Plaskacz, A. Rastawicka, W. Wojdecki, Warszawa 1984; P. Raina, 1978. Wybór Papieża...; Nie można zdradzić Ewangelii. Rozmowy z abp. Ignacym Tokarczukiem, oprac. M. Krzysztofiński, Rzeszów-Kraków 2013. Zob. też wspomnienia współpracowników i doradców prymasa Polski: W cieniu Prymasa Tysiaclecia. $Z$ profesorem Romualdem Kukotowiczem rozmawia Piotr Baczek, Warszawa 2001; B. Piasecki, M. Zając, Prymas Wyszyński nieznany. Ojciec duchowy widziany $z$ bliska, Kraków 2016. 
pontyfikatu Jana Pawła II najtrafniej oddał prymas Stefan Wyszyński, który w swoim podsumowaniu roku 1978 wskazywał, iż „Do wymiaru światowego należy bodaj wybór Polaka na Stolicę Piotrowa, poprzez tajemniczą śmierć II Papieży - Polska, tak bardzo krytykowana przez różne państwa (Francja, Belgia, Holandia, Niemcy), stała się nadzieja krajów katolickich ujawniona w wyborze Polaka na Głowę Kościoła, - i to takiego Polaka" ${ }^{10}$.

Radość i entuzjazm z powodu wyboru kard. Wojtyły na papieża wyrażało również rzecz jasna całe polskie społeczeństwo. Zupełnie inaczej zareagowały władze PRL. Dygnitarze partyjni przez dość długi czas mieli problemy z dostrzeżeniem konsekwencji wyboru kardynałów. Dominowały szok i niedowierzanie. Na posiedzeniu Komitetu Centralnego (KC) padła teza, która ochoczo podchwycono, że „Ostatecznie lepszy Wojtyła jako papież tam niż jako prymas tutaj" ${ }^{11}$. Trudno o większą krótkowzroczność. Jak się szybko okazało, władzom nie tylko udało się propagandowo zdyskontować wyboru Karola Wojtyły na papieża ${ }^{12}$, ale również musiano pójść na nieplanowane ustępstwa, takie jak rezygnacja z procedury terno przy wyborze biskupów ${ }^{13}$. Poza tym jednak nie zamierzano wprowadzać istotnych korekt do realizowanej w latach siedemdziesiątych polityki wobec Kościoła katolickiego ${ }^{14}$.

Bezpośrednio po konklawe polscy biskupi i sam papież zaczęli w publicznych wypowiedziach wspominać, iż przyjazd Jana Pawła II do Ojczyzny jest możliwy. Po raz pierwszy kwestia ta podniesiona została w komunikacie wydanym w Rzymie już 17 października przez sekretarza Episkopatu

${ }_{10}$ Zapis prymasa Wyszyńskiego z 31 XII 1978, w: P. Raina, Kardynat Wyszyński. Czasy prymasowskie 1978..., s. 270. Zob. też: idem, 1978. Wybór papieża..., s. 181-182.

11 K. Kakkol, Spowiedź pogromcy Kościoła, Olsztyn 1994, s. 90; A. Dudek, Ślady PeeRelu. Ludzie, wydarzenia, mechanizmy, Kraków 2005, s. 141-142. Na ten temat zob. też: A. Friszke, M. Zaremba, Wokót pierwszej pielgrzymki, w: Wizyta Jana Pawła II..., s. 27-31.

12 Szerzej na ten temat zob. J. Żaryn, Dzieje Kościoła..., s. 401-405; A. Dudek, R. Gryz, op. cit., s. $340-343$.

13 A. Dudek, R. Gryz, op. cit., s. 343-344; R. Łatka, Polityka władz PRL wobec Kościoła katolickiego w województwie krakowskim w latach 1980-1989, Kraków 2016, s. 89.

${ }^{14}$ A. Dudek, R. Gryz, op. cit., s. 340-344; R. Gryz, Między liberalizacja a dezintegracja. Stosunki państwo-Kościót w latach siedemdziesiatych, w: Stosunki państwo-Kościót..., s. 88-89. Na temat polityki wyznaniowej władz PRL w latach siedemdziesiątych szerzej zob. K. Pawlicka, Polityka wtadz wobec Kościoła katolickiego (grudzień 1970 - październik 1978), Warszawa 2004; K. Maniewska, Kościót katolicki w Bydgoszczy wobec prób laicyzacji i dezintegracji społeczeństwa w okresie rzadów Edwarda Gierka (1970-1980), Warszawa 2007; J. Żaryn, Stosunki państwo-Kościót katolicki $w$ latach siedemdziesiatych XX w., w: „Oaza wolności”. Duszpasterstwa Akademickie w PRL w latach siedemdziesiatych XX w., red. M. Marcinkiewicz, Szczecin 2011, s. 11-19; R. Gryz, Kierunki polityki wyznaniowej $w$ dekadzie Edwarda Gierka, w: Priorytety polityki wyznaniowej władz Polski „ludowej”, red. R. Łatka, „Glaukopis” 2016, nr 33, s. 286-306. Zob. też: Plany pracy Departamentu IV MSW na lata 1972-1979, oprac. M. Biełaszko i in., Warszawa 2007. Por. z dokumentacja Urzędu do Spraw Wyznań z tego okresu: A. Friszke, PRL wobec Kościoła. Akta Urzędu do Spraw Wyznań 1970-1978, Warszawa 2010. 
bpa Bronisława Dąbrowskiego, który wyrażał nadzieję, iż Ojciec Święty weźmie udział w uroczystościach 900-lecia męczeńskiej śmierci św. Stanisława oraz jubileuszu 600-lecia obrazu Matki Boskiej Częstochowskiej na Jasnej Górze $^{15}$. Słowa bpa Dąrowskiego potwierdził kard. Stefan Wyszyński 6 XI 1978 w katedrze św. Jana w Warszawie, mówiąc:

Jest nadzieja na to, że Ojciec Święty chce jak najprędzej przybyć do Polski. Najlepszą sposobnością są uroczystości świętego Stanisława w Krakowie, zapowiedziane na 13 maja przyszłego roku. Może przy tej okazji Ojciec Święty zobaczy nie tylko Kraków i Częstochowę. Ale pozwólcie, że jako człowiek dyskretny zamknę usta i nie pozwolę mówić memu sercu, a powierzę te myśli waszym sercom. Co wymodlicie, to będzie zyskiem Kościoła w Polsce i w Rzymie ${ }^{16}$.

Pod koniec tego miesiąca zaś jasno poinformowano o tym w Komunikacie z posiedzenia Konferencji Episkopatu Polski ${ }^{17}$.

Wobec takiego obrotu sprawy władze stawiały opór, nie chcac działać pod presją faktów dokonanych. W czasie rozmowy z sekretarzem Episkopatu

${ }^{15}$ Komunikat Sekretarza Episkopatu Polski z 17 X 1978, Warszawa-Rzym, w: P. Raina, 1978. Wybór papieża..., s. 137-138; idem, Kardynat Wyszyński. Czasy prymasowskie 1978..., s. 226; idem, Kardynat Wyszyński. Czasy prymasowskie 1979..., s. 11; A. Friszke, M. Zaremba, op. cit., s. 31. Sam Jan Paweł II wyraził chęć pielgrzymki w liście skierowanym do prymasa i Episkopatu Polski z 21 XI 1978. AAW, SPP, 04/33, Rada Główna Episkopatu Polski 1978, List Jana Pawła II do Episkopatu Polski, 21 XI 1978, Watykan, k. 175-176; ibidem, Protokół Rady Głównej Episkopatu Polski z 27 XI 1978, k. 184. Publicznie zaś głos na ten temat zabrał 23 października w czasie otwartej audiencji dla Polaków, gdy jednoznacznie zadeklarował wolę przyjazdu do Ojczyzny. AAW, SPP, 04/34, Rada Główna Episkopatu Polski 1979, Protokół Rady Głównej Episkopatu Polski z 9 III 1979, k. 38; P. Raina, 1978. Wybór papieża..., s. 151-155. Jak wspomniał Kazimierz Kakol w czasie swojej wypowiedzi dla dziennikarzy PAP z 5 IV 1979 r., „Sprawa przyjazdu Papieża do Polski zaczęła się już w minutę po wyborze Jana Pawła II. Następnego dnia, to znaczy 17 października o godzinie 14 musiałem odpowiadać na pytania, czy papież zostanie przyjęty”. AAW, SPP, 04/119, Sekretarz Episkopatu, Pro memoria. Wyjątki z wypowiedzi min. K. Kąkola dla dziennikarzy PAP, wygłoszonej dn. 5 IV 1979, 30 V 1979, Warszawa, k. 30.

${ }^{16}$ Cyt. za: R. Łatka, Wstep, w: Pielgrzymki Jana Pawła II..., s. 12. Zob. też: M. Lasota, Donos na Wojtytę..., s. 281; P. Raina, Kardynat Wyszyński. Czasy Prymasowskie 1979..., s. 12. Jak warto podkreślić, wypowiedź prymasa cytowano w Radiu Wolna Europa, gdzie w audycji 7 XI 1978 podkreślono, iż „Prymas wspomniał o możliwości przyjazdu Jana Pawła II do Polski z okazji uroczystości ku czci św. Stanisława w maju przyszłego roku. Powiedział, że po wyborze Polaka na Stolicę Apostolską Polska znalazła się teraz na ustach całego świata. Jest to - jak twierdził - nie tylko powód dumy i radości Polaków, ale nakłada również zwiększona odpowiedzialność. Społeczeństwo polskie powinno udzielić poparcia Papieżowi, który wyszedł z niego podnosząc poziom swych postaw moralnych". Cyt. za: AAW, SPP, 04/33, Rada Główna Episkopatu Polski 1978, Załącznik do Protokołu z posiedzenia Rady Głównej z 27 XI 1978 r. RWE 7 XI 1978, „Fakty, wydarzenia, opinie”. Kazanie Księdza Kardynała Stefana Wyszyńskiego w katedrze św. Jana a twierdzenia Gierka w Sejmie, k. 177.

17 J. Żaryn, Dzieje Kościoła..., s. 405; A. Dudek, R. Gryz, op. cit., s. 344. 
bpem Bronisławem Dąbrowskim Stanisław Kania powiedział, że o wizycie Jana Pawła II w 1979 r. nie może być mowy ${ }^{18}$. Dylematy władz, związane $\mathrm{z}$ pielgrzymka papieska, najlepiej ujął $\mathrm{w}$ czasie swojego spotkania z prymasem jego doradca Romuald Kukołowicz, który - jak odnotował kard. Wyszyński - w odpowiedzi na pytanie, czy papież mógłby przyjechać do Ojczyzny, podkreślał: „w PZPR sa głosy przeciwne. Ale to byłaby ostateczna klęska Partii [sic!] w opinii publicznej. Chociaż PZPR zdaje sobie sprawę, że w dniach obecności Papieża w Polsce Partia [sic!] straciłaby resztę znaczenia. I tak źle i tak niedobrze"19.

Kardynał Wyszyński już na posiedzeniu RG z 27 XI 1978 r. wyraził w klarowny sposób stanowisko Jana Pawła II, że papież nie dopuszcza myśli, iż mógłby nie odwiedzić swojej Ojczyzny. Prymas wspominał również o swoim spotkaniu z kierownikiem Urzędu do Spraw Wyznań Kazimierzem Kąkolem, które odbyło się dzień wcześniej. Wspomniany dygnitarz partyjny zwracał przywódcy polskiego Kościoła uwagę na trudności ekonomiczne i kontrowersyjne dla władz okoliczności związane z uroczystościami ku czci św. Stanisława, na które miałby przybyć papież ${ }^{20}$. Wspomniany kontekst zauważyło również kilku członków RG, m.in. abp Henryk Gulbinowicz i abp Jerzy Stroba. Ten pierwszy powoływał się na swoją rozmowę z przedstawicielami władz KW PZPR we Wrocławiu, którzy jednoznacznie deklarowali, iż będzie zgoda na przyjazd Jana Pawła II, ale w wyznaczonym przez rząd terminie ${ }^{21}$. Prymas w podsumowaniu z posiedzenia Rady podkreślił, iż episkopat do rozmów z władzami przystapi dopiero wtedy, gdy Ojciec Święty ostatecznie to zadeklaruje i zleci „Episkopatowi przeprowadzenie rozmów sondażowych. Dopiero później możemy powołać Organizacyjne Komitety Lokalne"22. Do kwestii wizyty Jana Pawła II w swoim referacie, poświęconym analizie sytuacji

${ }_{18}$ A. Friszke, M. Zaremba, op. cit., s. 33.

19 Zapis prymasa Wyszyńskiego z 7 XI 1978, cyt. za: P. Raina, Kardynat Wyszyński. Czasy prymasowskie $1978 \ldots$... s. 266-267.

20 AAW, SPP, 04/33, Rada Główna Episkopatu Polski 1978, Protokół Rady Głównej Episkopatu Polski z 27 XI 1978, k. 185. Stanowisko Kąola potwierdził Kania w czasie spotkania z bpem Dąbrowskim, które odbyło się 11 XII 1978 r. Wyrażał wtedy obawy o bezpieczeństwo papieża oraz widział możliwość w „prowokacjach ze strony sił opozycyjnych”. W czasie tej rozmowy przedstawiciel władz partyjnych po raz pierwszy zadeklarował, iż optymalnym terminem wizyty byłyby uroczystości maryjne w 1982 r. AAW, SPP, 04/34, Rada Główna Episkopatu Polski 1979, Protokół Rady Głównej Episkopatu Polski z 9 III 1979, k. 38. Jak wiadomo z wielu dokumentów partyjnych, przyjazd Jana Pawła II na uroczystości stanisławowskie był dla władz nie do zaakceptowania. Szerzej zob. J. Żaryn, Dzieje Kościoła..., s. 405-406; R. Łatka, Polityka władz PRL..., s. 85-86.

${ }^{21}$ AAW, SPP, 04/33, Rada Główna Episkopatu Polski 1978, Protokół Rady Głównej Episkopatu Polski z 27 XI 1978, k. 185.

${ }^{22}$ Ibidem, k. 186. W dalszym ciagu biskupi traktowali jako termin przybycia Ojca Świętego uroczystości stanisławowskie w 1979 r. AAW, SPP, 04/295, Konferencja Plenarna Episkopatu Polski, Protokół Konferencji Plenarnej Episkopatu Polski z 28 i 29 XI 1979, k. 73-74. 
politycznej w kraju, odniósł się jeszcze bp Dąbrowski, który zauważył, iż „Centralne Władze [sic!] partyjne przyjęły postawę wyczekująca, przerażone perspektywą wizyty Ojca św. w Polsce" ${ }^{23}$. Strach przed konsekwencjami pielgrzymki popchnał władze do złożenia 14 grudnia protestu na ręce abpa Luigiego Poggiego. Jak relacjonował bp Dąbrowski: „Ojciec Święty nie mógł zrozumieć stanowiska rządu i oburzało Go to, że nie może odwiedzić własnej Ojczyzny"24. Jan Paweł II nie miał jednak zamiaru przyjmować stanowiska władz do wiadomości i 9 I 1979 r. w czasie watykańskiej konsekracji abpa Franciszka Macharskiego powiedział, że pielgrzymka do kraju na uroczystości stanisławowskie jest ,jego obowiązkiem”25. Sekretarz Episkopatu wskazywał ten moment jako bardzo istotny dla wydania przez dygnitarzy partyjnych zgody na pielgrzymkę, gdyż władze zdały sobie wtedy sprawę, iż polski papież nie zrezygnuje z przyjazdu do Ojczyzny. Stanowisko to uwidoczniło się w czasie kolejnego spotkania Kani i Dąbrowskiego 12 I 1979 r., gdy ten pierwszy zajął łagodniejsze niż wcześniej stanowisko, nie odsuwając terminu przyjazdu Ojca Świętego do 1982 r. (równocześnie jednak zauważajacc, iż na majowy termin nie będzie zgody władz) ${ }^{26}$.

${ }^{23}$ AAW, SPP, 04/33, Rada Główna Episkopatu Polski 1978, Protokół Rady Głównej Episkopatu Polski z 27 XI 1978, k. 187.

${ }^{24}$ AAW, SPP, 04/34, Rada Główna Episkopatu Polski 1979, Protokół Rady Głównej Episkopatu Polski z 9 III 1979, k. 39.

${ }^{25}$ Ibidem, k. 39; AAW, SPP, 04/297, Konferencja Plenarna Episkopatu Polski z 21-22 III 1979, Protokół Konferencji Plenarnej Episkopatu Polski z 21-22 III 1979, k. 29. Warto też dodać, iż równie stanowczo kwestię przyjazdu stawiali przedstawiciele polskiego Kościoła. W czasie spotkania ministra Kąkola z ks. Alojzym Orszulikiem, pełniącym funkcję dyrektora Biura Sekretariatu Episkopatu Polski, 19 XII 1978 r. ten drugi zgodnie z poleceniem prymasa jasno mówił, jakie będą konsekwencje odmownej decyzji władz w kwestii pielgrzymki: „1) Ksiądz Prymas obawia się, że gdy to przecieknie do społeczeństwa, to moga powstać niepokoje i trudności, zwłaszcza w tej niełatwej sytuacji ekonomicznej; 2) a gdy te wiadomości przedostaną się do prasy światowej, w krajach zachodnich może to podważyć zaufanie do Polski, co z kolei może spowodować utrudnienia w uzyskaniu kredytów i innej pomocy. Może to postawić w trudnej sytuacji I Sekretarza”. Cyt. za: P. Raina, Wizyty..., s. 11; A. Dudek, R. Gryz, op. cit., s. 344-345.

${ }^{26}$ AAW, SPP, 04/34, Rada Główna Episkopatu Polski 1979, Protokół Rady Głównej Episkopatu Polski z 9 III 1979, k. 39; P. Raina, Kardynat Wyszyński. Czasy prymasowskie $1979 \ldots$, s. 21-22. Jak podkreślał Kania, dobra okazją do wizyty byłby jasnogórski jubileusz z okazji 600-lecia pobytu obrazu Matki Boskiej Częstochowskiej na Jasnej Górze, oraz dodał: „Jeżeliby Papież zechciał skorzystać z tej oferty, spotka się z życzliwym przyjęciem i zaproszeniem. Nikomu przecież nie są potrzebne uprzedzające oświadczenia, tak jak do pielgrzymki krakowskiej. Papież powiedział, że uważa swój przyjazd do Krakowa za obowiązek”. Cyt. za: AAW, SPP, Kościół-Państwo, 25, Materiały z rozmowy z Edwardem Gierkiem, I sekretarzem KC PZPR, 24 I 1979, Problemy do rozmowy Prymasa Polski z Edw. Gierkiem (24 I 1979), Notatka Sekretarza Episkopatu bp. Bronisława Dąbrowskiego ze spotkania z Sekretarzem KC PZPR Stanisławem Kanią w dniu 12 I 1979. Zob. też: AAW, SPP, 04/296, Konferencja Plenarna Episkopatu Polski 7-8 II 1979, Protokół Konferencji Plenarnej Episkopatu Polski z 7 i 8 II 1979, k. 13-14. 
Dopiero w czasie spotkania prymasa Wyszyńskiego z Gierkiem 24 I 1979 r. I sekretarz PZPR oświadczył, że Ojciec Święty ma prawo przybyć do kraju, co oznaczało zgodę władz PRL na pielgrzymkę ${ }^{27}$. Wspomniane spotkanie miało kluczowe znaczenie dla powodzenia negocjacji. Jak wynika z dokumentacji zgromadzonej w Sekretariacie Episkopatu Polski, kard. Wyszyński wiele uwagi przywiązywał do przygotowania się do spotkania z I sekretarzem PZPR ${ }^{28}$. Kwestię pielgrzymki prymas zamierzał poruszyć w następujący sposób:

Znane jest pragnienie Papieża przyjazdu do Polski na uroczystości maryjne na Jasnej Górze i jubileuszowe 900-lecie śmierci św. Stanisława, biskupa krakowskiego w dniach 12-13 maja. Trudno temu pragnieniu nie wyjść naprzeciw. Nie powinno być przeszkód, byśmy mogli razem Rząd [sic!] i Episkopat w maju br. przyjać godnie Papieża - Syna Narodu Polskiego w naszym kraju. [...] Ufamy, że udział Ojca Św. w uroczystościach będzie doniosłym wkładem w dalsze podnoszenie znaczenia Polski na forum światowym. Ufamy, że władze polskie dadzą wyraz zadowolenia z tej gotowości przybycia Ojca św. do Polski².

Prymas szczegółowo zrelacjonował przebieg swojego spotkania z Gierkiem członkom RG Episkopatu, na podstawie swoich notatek sporządzonych w czasie rozmowy z I sekretarzem PZPR ${ }^{30}$. Jak podkreślił kard. Wyszyński na posiedzeniu RG z 6 II 1979 r., dobrze przygotował się do rozmowy i trwała ona cztery godziny. Kwestie wizyty prymas wpisał w ogólną sytuację Kościoła w realiach PRL, zwracając uwagę na szereg problemów we wzajemnych relacjach ${ }^{31}$.

${ }^{27}$ Jak warto podkreślić, decyzję o zgodzie władz na przyjazd Jana Pawła II do PRL Gierek podjął wbrew stanowisku Breżniewa. A. Dudek, op. cit., s. 144-145; A. Friszke, M. Zaremba, op. cit., s. 36-38.

${ }^{28} \mathrm{~W}$ dokumentacji Episkopatu znajduje się kilka przygotowanych wariantów rozmowy z Gierkiem, na których prymas nanosił odręczne poprawki. AAW, SPP, Kościól-Państwo, 25, Materiały z rozmowy z Edwardem Gierkiem, I sekretarzem KC PZPR, 24 I 1979. Problematyka wizyty Jana Pawła II była tylko jednym z tematów rozmowy, poza tym omawiano głównie relacje państwo-Kościół. Szerzej zob. ibidem, S. Wyszyński, Tematy do rozmowy w dniu 24 I 1979; ibidem, Problemy do rozmowy Prymasa Polski z Edw. Gierkiem (24 I 1979). Zob. też: AAW, SPP, 04/34, Rada Główna Episkopatu Polski 1979, Summa Pontifici. Wypowiedzi na Radzie Głównej Episkopatu Polski, 5 VI 1979, k. 76. Zob. też: P. Raina, Kardynał Wyszyński. Czasy prymasowskie 1979..., s. 22-24. Należy dodać, iż prymas tematykę rozmowy i sposób argumentacji konsultował z bpem Dąbrowskim. Ibidem, List bp. Bronisława Dąbrowskiego do prymasa Stefana Wyszyńskiego z 20 I 1979.

${ }^{29}$ AAW, SPP, Kościół-Państwo, 25, Materiały z rozmowy z Edwardem Gierkiem, I sekretarzem KC PZPR, 24 I 1979, S. Wyszyński, Tematy do rozmowy w dniu 24 I 1979 (dział: Przyjazd Papieża Jana Pawła II do Polski w maju 1979 r.).

${ }^{30}$ Ibidem, Materiały z rozmowy z Edwardem Gierkiem, I sekretarzem KC PZPR, 24 I 1979. Analogiczna, choć zdecydowanie mniej obszerną relację prymas przedstawił biskupom na Konferencji Plenarnej w dniach 7-8 lutego. AAW, SPP, 04/296, Konferencja Plenarna Episkopatu Polski 7-8 II 1979, Protokół Konferencji Plenarnej Episkopatu Polski z 7 i 8 II 1979, k. 12-13.

${ }^{31}$ Kościót w PRL..., s. 127; P. Raina, Kardynał Wyszyński. Czasy prymasowskie 1979..., s. 25-28. 
Przytaczając przebieg dyskusji na temat pielgrzymki, kard. Wyszyński zauważał, iż „Nad sprawa wizyty Ojca św. potoczyła się dłuższa rozmowa. Pan Gierek miał cały wywód napisany, wracał do hasła, do sporu biskupa z królem, i wykluczył możliwość przyjazdu Papieża na uroczystości krakowskie" ${ }^{32}$. Jak podkreślał prymas, I sekretarz PZPR w ogóle nie chciał wziąć pod uwagę jego argumentów i sugerował odłożenie wizyty na uroczystości maryjne w 1982 r. ${ }^{33}$ Prymas nie zaakceptował tego rodzaju argumentacji Gierka i zaproponował powołanie komisji kościelno-rządowej do rozstrzygnięcia kwestii terminu pielgrzymki. I sekretarz wyraził na to zgodę, tym samym zgadzając się na przyjazd Jana Pawła $\mathrm{II}^{34}$. Na czele Komisji Mieszanej, zgodnie z wolą rozmówców, stanęli bp Dąbrowski i Kania ${ }^{35}$. Prymas, mimo iż rozmowa nie była przyjemna, oceniał ją pozytywnie ${ }^{36}$. Choć spotkanie „na

${ }^{32}$ AAW, SPP, 04/34, Rada Główna Episkopatu Polski 1979, Protokół Rady Głównej Episkopatu Polski z 6 II 1979, k. 14. Por. z relacją bpa Dąbrowskiego: ibidem, Protokół Rady Głównej Episkopatu Polski z 9 III 1979, k. 39. Zob. też: AAW, SPP, 04/299, Konferencja Plenarna Episkopatu Polski z 5-6 IX 1979, Protokół z konferencji księży biskupów ordynariuszów dnia 5 IX 1979, k. 68.

${ }^{33}$ AAW, SPP, Kościół-Państwo, 25, Materiały z rozmowy z Edwardem Gierkiem, I sekretarzem KC PZPR, 24 I 1979, Problemy do rozmowy Prymasa Polski z Edw. Gierkiem (24 I 1979).

${ }^{34}$ Kardynał Wyszyński wspominając w czasie posiedzenia RG tę rozmowę, przywołał argumenty, które wysuną pod adresem Gierka: „Powiedziałem: Panowie, jeśli nie przyjedzie Ojciec Święty, Kościół nic na tym nie straci, bo Kościół i tak wierzy, hierarchicznie wierzy. Ale na was spadnie za to odpowiedzialność. Jeżeli przyjedzie Ojciec Święty, to Wy możecie też coś skorzystać. Wielka część opinii publicznej powie: jednakże najgorszymi oni nie sa, troszkę po polsku myśla, bo się zgodzili na przyjazd Ojca Świętego". Cyt. za: AAW, SPP, 04/34, Rada Główna Episkopatu Polski 1979, Protokół Rady Głównej Episkopatu Polski z 5 VI 1979, k. 103. Zob. też: AAW, SPP, 04/296, Konferencja Plenarna Episkopatu Polski 7-8 II 1979, Protokół Konferencji Plenarnej Episkopatu Polski z 7 i 8 II 1979, k. 13.

35 AAW, SPP, 04/34, Rada Główna Episkopatu Polski 1979, Protokół Rady Głównej Episkopatu Polski z 6 II 1979, k. 14; ibidem, Protokół Rady Głównej Episkopatu Polski z 9 III 1979, k. 39; AAW, SPP, Kościół-Państwo, 25, Materiały z rozmowy z Edwardem Gierkiem, I sekretarzem KC PZPR, 24 I 1979, Problemy do rozmowy Prymasa Polski z Edw. Gierkiem (24 I 1979). Warto dodać, iż I sekretarz PZPR po spotkaniu z kard. Wyszyńskim miał świadomość, że prymas chciał wykorzystać kłopoty władz związane z trudną sytuacja ekonomiczna oraz „obecność Polaka na tronie papieskim do umocnienia religijnej i politycznej pozycji kościoła [sic!] w społeczeństwie”. A. Friszke, M. Zaremba, op. cit., s. 36; A. Dudek, R. Gryz, op. cit., s. 345. W dokumentacji kościelnej znalazły się również materiały dotyczące opinii emigracji na temat rozmowy i jej efektów. Jak podkreślano w audycji „Fakty, wydarzenia, opinie” Radia Wolna Europa z 29 I 1979 r., „Obserwatorzy zachodni w dalszym ciagu zastanawiają się czy zeszłotygodniowe spotkanie pomiędzy Prymasem Polski Kardynałem Stefanem Wyszyńskim, i szefem PZPR Gierkiem utorowało ostatecznie drogę przyjazdowi Papieża na majowe uroczystości w Krakowie z okazji 900-tnej rocznicy męczeństwa św. Stanisława Patrona Polski”. Cyt. za: AAW, SPP, Kościół-Państwo, 25, Materiały z rozmowy z Edwardem Gierkiem, I sekretarzem KC PZPR, 24 I 1979, Problemy do rozmowy Prymasa Polski z Edw. Gierkiem (24 I 1979).

36 AAW, SPP, 04/34, Rada Główna Episkopatu Polski 1979, Summa Pontifici. Wypowiedzi na Radzie Głównej Episkopatu Polski, 5 VI 1979, k. 76. Co ciekawe, wraz z biegiem czasu 
szczycie" miało kluczowe znaczenie dla uzgodnienia kwestii wizyty Jana Pawła II w Ojczyźnie (szczególnie powołanie zespołu organizacyjnego), nie oznacza to jednakże, iż wszystkie jej warunki zostały uzgodnione, z najważniejszym na czele, czyli terminem pielgrzymki. Negocjacje toczyły się jeszcze przez kilka kolejnych miesięcy. Były one przedmiotem wielu dyskusji w łonie najważniejszej struktury polskiego Kościoła. Należy jednak dodać, iż oczywiście na bieżąco konsultowano je z polskim papieżem. To właśnie Jan Paweł II był „ostateczną instancja”, jeśli chodzi o generalne kwestie związane z wizytą ${ }^{37}$, ale już za szczegółowy program i ustalenia z władzami odpowiadał Episkopat, a przede wszystkim prymas Wyszyński oraz jego główny współpracownik bp Dąrowski ${ }^{38}$.

W czasie posiedzenia RG w lutym 1979 r. sekretarz Episkopatu zrelacjonował swoje spotkania z Kanią i Kąkolem, dotyczace przyjazdu Ojca Świętego. Podobnie jak podczas posiedzenia Rady w listopadzie 1978 r., podkreślał strach dygnitarzy partyjnych związany z wizyta. Niemniej jednak, jak zauważał, władze centralne ważyły zyski i straty odnośnie do wizyty, zastanawiając się, co przeważy ${ }^{39}$. Ostatecznie po krótkiej dyskusji RG uznała, iż pielgrzymka papieska winna mieć charakter ogólnopolski oraz odbywać się w terminie wyznaczonym wcześniej przez Jana Pawła II, tzn. w dniach 9-15 V 1979 r. W razie nieprzejednanego podejścia władz w negocjacjach jako termin rezerwowy proponowano dni: 2-7 maja. Takie podejście miał prezentować bp Dąbrowski w czasie spotkań z dygnitarzami partyjnymi na forum komisji kościelno-rządowej ${ }^{40}$. Ponadto uzgodniono, iż po zakończeniu rozmów

rozmowę z Gierkiem prymas odbierał coraz bardziej pozytywnie. Szerzej zob. ibidem, Protokół Rady Głównej Episkopatu Polski z 26 VI 1979, k. 134-135; ibidem, S. Wyszyński, Uwagi i obserwacje po pobycie Ojca św. Jana Pawła II w Polsce, VIII 1980, k. 246. Zob. też: ibidem, Protokół Rady Głównej Episkopatu Polski z 4 IX 1983, k. 264-265. Należy w tym miejscu również wspomnieć, że także strona partyjna oceniała, iż rozmowa „do przyjemnych nie należała”. Informacja Edwarda Gierka o rozmowie z Kardynałem Stefanem Wyszyńskim przekazana zapewne w czasie telekonferencji z I sekretarzami Komitetów Wojewódzkich PZPR, [b.d.], w: Wizyta Jana Pawła II..., s. 115-119; M.F. Rakowski, Dzienniki polityczne 1979-1981, Warszawa 2004, s. 44; A. Friszke, M. Zaremba, op. cit., s. 35-36.

37 Jednoznacznie mówiono o tym w czasie kilku posiedzeń RG Episkopatu, m.in. 27 XI 1978 czy 6 II 1979. Szerzej zob. AAW, SPP, 04/33, Rada Główna Episkopatu Polski 1978, Protokół Rady Głównej Episkopatu Polski z 27 XI 1978, k. 186; AAW, SPP, 04/34, Rada Główna Episkopatu Polski 1979, Protokół Rady Głównej Episkopatu Polski z 6 II 1979, k. 14-16.

${ }^{38}$ Wynikało to rzecz jasna z ich pozycji w polskim Kościele: prymasa jako niekwestionowanego przywódcy, a bpa Dąbrowskiego jako odpowiedzialnego za kontakty z władzami.

39 AAW, SPP, 04/34, Rada Główna Episkopatu Polski 1979, Protokół Rady Głównej Episkopatu Polski z 6 II 1979, k. 14. Prymas efekty rozmów zrelacjonował również na Konferencji Plenarnej. AAW, SPP, 04/296, Konferencja Plenarna Episkopatu Polski 7-8 II 1979, Protokół Konferencji Plenarnej Episkopatu Polski z 7 i 8 II 1979, k. 12.

${ }^{40}$ AAW, SPP, 04/34, Rada Główna Episkopatu Polski 1979, Protokół Rady Głównej Episkopatu Polski z 6 II 1979, k. 15-16; AAW, SPP, 04/296, Konferencja Plenarna Episkopatu Polski 7-8 II 1979, Protokół Konferencji Plenarnej Episkopatu Polski z 7 i 8 II 1979, k. 15-16. 
w Komisji Mieszanej do Watykanu uda się sekretarz Episkopatu, który przedstawi papieżowi efekty negocjacji z władzami i stanowisko tejże instytucji ${ }^{41}$.

14 lutego zaczęła funkcjonować Komisja Mieszana Episkopatu i władz PRL, której utworzenie uzgodnili wcześniej prymas i I sekretarz PZPR. W jej skład wchodzili ze strony kościelnej: bp Dąbrowski, abp Macharski i ks. Alojzy Orszulik, ze strony władz: Kania, Kąkol i Józef Czyrek, wiceminister spraw zagranicznych ${ }^{42}$. Zgodnie z wytycznymi RG przedstawiciele Episkopatu podtrzymywali majowy termin wizyty ${ }^{43}$, napotkali jednakże pod tym względem silny opór dygnitarzy partyjnych, którzy kategorycznie oponowali przeciw temu ${ }^{44}$. Efekt spotkania Komisji Mieszanej, a raczej jego brak, pojechali do Watykanu przedstawić bp Dabrowski i abp Macharski ${ }^{45}$. Przebywali tam w dniach 20-26 lutego, rozmawiając z Janem Pawłem II na temat możliwych terminów pielgrzymki. Polski papież podał dwie propozycje: 2-10 czerwca i 9-17 czerwca $^{46}$. Po powrocie delegacji RG do kraju kard. Wyszyński polecił bpowi Dąbrowskiemu porozmawiać z Kanią i przedstawić mu tylko pierwszy ze wspomnianych terminów, jako oficjalna propozycję Episkopatu ${ }^{47}$. Dzień później, 27 lutego sekretarz Episkopatu spotkał się ze wspomnianym dygnitarzem partyjnym, podajac daty 2-10 czerwca jako jedyny możliwy termin oraz wyrażając w imieniu Jana Pawła II „ubolewanie, że nie może przybyć do Polski w maju i, że tak negatywnie władze traktuja św. Stanisława"48. Kania odpowiedział, iż musi uzyskać zgodę kierownictwa partyjnego i rządu,

${ }^{41}$ Po ostatecznym ustaleniu terminu do Watykanu miała się również udać delegacja Episkopatu, by podziękować Ojcu Świętemu za chęć przybycia do Ojczyzny. AAW, SPP, 04/34, Rada Główna Episkopatu Polski 1979, Protokół Rady Głównej Episkopatu Polski z 6 II 1979, k. 16.

${ }^{42}$ Ibidem, Protokół Rady Głównej Episkopatu Polski z 9 III 1979, k. 40; A. Dudek, R. Gryz, op. cit., s. 345; P. Raina, Kardynat Wyszyński. Czasy Prymasowskie 1979..., s. 30.

${ }^{43}$ Stanowisko Kościoła precyzowały „Punkty do rozmowy dla Komisji w sprawie przyjazdu Ojca Świętego”, przygotowane przez bp. Dąbrowskiego. AAW, SPP, Kościół-Państwo, 25, Materiały z rozmowy z Edwardem Gierkiem, I sekretarzem KC PZPR, 24 I 1979, Problemy do rozmowy Prymasa Polski z Edw. Gierkiem (24 I 1979), Punkty do rozmowy dla Komisji w sprawie przyjazdu Ojca Świętego.

${ }^{44}$ AAW, SPP, 04/34, Rada Główna Episkopatu Polski 1979, Protokół Rady Głównej Episkopatu Polski z 9 III 1979, k. 40-42; A. Friszke, M. Zaremba, op. cit., s. 38-39; A. Dudek, R. Gryz, op. cit., s. 345-346.

${ }^{45}$ AAW, SPP, 04/34, Rada Główna Episkopatu Polski 1979, Protokół Rady Głównej Episkopatu Polski z 9 III 1979, k. 40-41; AAW, SPP, 04/297, Konferencja Plenarna Episkopatu Polski z 21-22 III 1979, Protokół Konferencji Plenarnej Episkopatu Polski z 21-22 III 1979, k. 30. Por. Depesza Stanisława Kani i Emila Wojtaszka do Kazimierza Szablewskiego z 19 II 1979 r., w: Wizyta Jana Pawta II..., s. 121-122.

${ }^{46}$ AAW, SPP, 04/34, Rada Główna Episkopatu Polski 1979, Protokół Rady Głównej Episkopatu Polski z 9 III 1979, k. 41. Władze nie miały pełnych informacji na ten temat. Szerzej zob. A. Friszke, M. Zaremba, op. cit., s. 39-40.

${ }^{47}$ AAW, SPP, 04/34, Rada Główna Episkopatu Polski 1979, Protokół Rady Głównej Episkopatu Polski z 9 III 1979, k. 41.

${ }^{48}$ Ibidem, k. 41. Zob. też: P. Raina, Arcybiskup Dąbrowski-rozmowy watykańskie..., s. 194-198. 
wobec czego przedłoży im propozycję Episkopatu. Jak pokazuje protokół RG z 9 marca, członkowie tego gremium znali przebieg posiedzenia Biura Politycznego (BP), które odbyło się w tym samym dniu co spotkanie Kani i bpa Dąbrowskiego. Prymas Wyszyński miał odczytać poufną notatkę dotycząca stanowiska poszczególnych członków BP KC, z których część na czele z Gierkiem postulowała wrześniowy termin pielgrzymki (niestety wspomnianej notatki nie odnalazłem w dokumentacji AAW, SPP ${ }^{49}$.

Negocjacje co do terminu wizyty papieża zakończyły się ostatecznie 1 marca - w czasie posiedzenia Komisji Mieszanej dygnitarze partyjni wyrazili zgodę na pobyt Jana Pawła II w Ojczyźnie w dniach 2-10 czerwca ${ }^{50}$. Władzom udało się ominać rocznicę śmierci św. Stanisława, co poczytywano sobie za duży sukces ${ }^{51}$. KC jeszcze w tym samym dniu zaakceptował datę przyjazdu papieża $^{52}$. Po posiedzeniu wspomnianej Komisji ks. Orszulik uzyskał ostateczna aprobatę kard. Wyszyńskiego, a bp Dąbrowski - Jana Pawła II, z którym odbył rozmowę telefoniczna ${ }^{53}$. Dzień później ustalenia ogłoszono publicznie ${ }^{54}$.

\section{Przygotowania Kościoła do pielgrzymki, uzgadnianie szczegółów wizyty}

Kolejne (tym razem nadzwyczajne) posiedzenie RG Episkopatu odbyło się już po oficjalnym ustaleniu i ogłoszeniu terminu przyjazdu Jana Pawła II do Ojczyzny, 9 III 1979 r. W całości poświęcono je tematyce wizyty Ojca Świętego ${ }^{55}$. RG zgodnie ze wskazaniem prymasa zajęła się ustaleniem kierunku prac związanych z przygotowaniem pielgrzymki oraz sugestiami co do programu, jakie należało przedstawić papieżowi. Po wprowadzeniu, dokonanym przez kard. Wyszyńskiego, szczegółowo etapy negocjacji z władzami przekazał bp Dąbrowski ${ }^{56}$. Prymas zarysował wstępny program pielgrzymki

${ }_{49}$ AAW, SPP, 04/34, Rada Główna Episkopatu Polski 1979, Protokół Rady Głównej Episkopatu Polski z 9 III 1979, k. 41.

50 Ibidem, Protokół Rady Głównej Episkopatu Polski z 9 III 1979, k. 41-42; P. Raina, Wizyty..., s. 28-33; A. Friszke, M. Zaremba, op. cit., s. 41-43.

${ }^{51}$ Archiwum Narodowe w Krakowie, 29/2382/435, KK PZPR Wydz. Organizacyjny. Informacje bieżące o sytuacji politycznej i gospodarczej w woj. miejskim krakowskim, Informacja Bieżąca z 5 III 1979, k. 203; A. Friszke, M. Zaremba, op. cit., s. 33-36.

${ }^{52}$ Protokół z posiedzenia Biura Politycznego KC PZPR w dniu 1 III 1979, w: Wizyta Jana Pawta II..., s. 130. Por. AAW, SPP, 04/297, Konferencja Plenarna Episkopatu Polski z 21-22 III 1979, Protokół Konferencji Plenarnej Episkopatu Polski z 21-22 III 1979, k. 30.

${ }^{53}$ AAW, SPP, 04/34, Rada Główna Episkopatu Polski 1979, Protokół Rady Głównej Episkopatu Polski z 9 III 1979, k. 41; P. Raina, Arcybiskup Dabrowski-rozmowy watykańskie..., s. 201-202.

${ }^{54}$ A. Dudek, R. Gryz, op. cit., s. 345.

${ }_{55}$ AAW, SPP, 04/34, Rada Główna Episkopatu Polski 1979, Protokół Rady Głównej Episkopatu Polski z 9 III 1979, k. 37-51.

${ }^{56}$ Ibidem, k. 38-40. 
Jana Pawła II, zgodnie z którym miał on przybyć do Warszawy 2 czerwca, dzień później wyjechać do Gniezna, 4 czerwca uczestniczyć w uroczystościach na Jasnej Górze, gdzie weźmie również udział w Konferencji Plenarnej i RG Episkopatu w dniach 5-6 czerwca, następnie 7 czerwca uda się do Krakowa. Zgodnie z poleceniem prymasa szczegółowy program pobytu w archidiecezji krakowskiej miał opracować abp Macharski ${ }^{57}$. Ponadto kard. Wyszyński dokonał - jak to ujął - „rejonizacji” pielgrzymki, polecając, którzy biskupi powinni uczestniczyć w jakich uroczystościach, podkreślając, że w Częstochowie obecni maja być wszyscy hierarchowie ${ }^{58}$. Tego typu sposób przedstawienia tej sprawy pokazuje jasno, iż prymas był niekwestionowanym przywódca polskiego Kościoła, którego poleceniom bez dyskusji podporządkowywali się pozostali członkowie RG Episkopatu. Ponadto Rada powołała Komitet Honorowy Przyjęcia Ojca Świętego oraz Ogólnopolski Kościelny Komitet Koordynacyjny mający za zadanie na bieżąco współpracować z władzami przy przygotowaniach do wizyty - należało skoncentrować się na uzgodnieniu następujących kwestii:

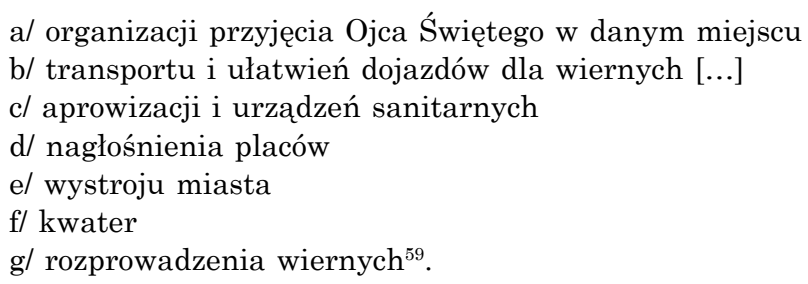

Jak widać z powyższego katalogu, Komitet Koordynacyjny pełnił funkcje o charakterze czysto wykonawczym. Jego pracę miały uzupełniać komitety lokalne w Warszawie, Gnieźnie, Częstochowie i Krakowie, powołane również postanowieniem RG z 9 marca. Za kontakty z władzami wojewódzkimi najwyższego szczebla winni odpowiadać osobiście ordynariusze diecezji ${ }^{60}$. Inna ważną struktura, którą zdecydowano się wtedy utworzyć, było Biuro Informacyjne, umiejscowione przy Komitecie Koordynacyjnym, powołane w celu przygotowywania dla mediów zagranicznych rzetelnych informacji o życiu Kościoła w Polsce. Jego pracę powinien koordynować ks. Orszulik; należeli do niego: ks. Waldemar Wojdecki, ks. Jerzy Dąbrowski, ks. Józef Maj (miało posiadać również swoje lokalne odpowiedniki) ${ }^{61}$.

Ostatnim akordem posiedzenia Rady z 9 marca było poinformowanie przez prymasa jej członków, że do Watykanu 10 marca wybierze się delegacja mająca za zadanie podziękować Janowi Pawłowi II za chęć przyjazdu oraz

\footnotetext{
${ }^{57}$ Ibidem, k. 42-43.

58 Ibidem, k. 43-44.

${ }^{59}$ Ibidem, k. 47.

${ }^{60}$ Ibidem, k. 47.

${ }^{61}$ Ibidem, k. 48-49.
} 
uzgodnić z nim szczegóły programu wizyty. W jej skład weszli: bp Dąbrowski, abp Macharski i bp Stefan Bareła, ordynariusz częstochowski ${ }^{62}$. W dokumentacji kościelnej zachowało się dość obszerne sprawozdanie z wizyty delegacji u Jana Pawła II, sporządzone przez sekretarza Episkopatu ${ }^{63}$. Jak wynika z tego dokumentu, w pracy nad programem pielgrzymki, oprócz członków delegacji i samego Ojca Świętego, brali udział sekretarz papieża ks. Stanisław Dziwisz, ks. Tadeusz Pieronek i ks. Bronisław Fidelus, wicekanclerz kurii krakowskiej ${ }^{64}$. Pewien wpływ na organizację wizyty mieli również abp Agostino Casaroli oraz abp Giuseppe Caprio - szczególnie jeśli chodzi o kwestie związane z bezpieczeństwem papieża i obsługa prasowa pielgrzymki ${ }^{65}$. Najistotniejsze sprawy ustalone zostały w czasie spotkania Ojca Świętego z bpem Dąbrowskim i abpem Casarolim, które miało miejsce 15 marca. Jan Paweł II poruszył wtedy niezwykle istotną kwestię spotkań z władzami PRL oraz kształtu relacji państwo-Kościół.

Ojciec Święty zagajając spotkanie powiedział: Chce wrócić do mojej wizyty w Polsce. Ponieważ władze państwowe oficjalnie włączyły się w zaproszenie mnie do Polski muszę z władzami się spotkać. Idzie o formę, która będzie przez społeczeństwo do przyjęcia. Społeczeństwo jest bardzo wrażliwe. Myślę, że muszę się spotkać z Przewodniczącym i Radą Państwa, w terenie zaś z prezydentem i wojewodami, jeśli będą mnie witać. To nie stanowi problemu. Problem stanowi spotkanie z I sekretarzem, którego politycy traktuja jak głowę państwa. [...] Nie możemy stawiać na równi partii z rządem ${ }^{66}$.

Jan Paweł II dodał jednakże, że nie widzi trudności w prywatnym spotkaniu z Gierkiem. Następnie papież przeszedł do kwestii relacji państwo-Kościół, stwierdzając, że ich stan jest niezadowalający. Zwrócił uwagę na siłę polskiego Kościoła, który im silniejszy się stanie, tym łatwiej będzie Stolicy Apostolskiej prowadzić dialog z władzami. Jak trafnie podkreślał Ojciec Święty: „Wprawdzie polskie władze polityczne zmieniły swój stosunek do Kościoła i traktuja go jako partnera i chca współpracy, ale to wszystko nie jest oparte na solidnych podstawach" ${ }^{67}$. Ostatnie spotkanie z Janem Pawłem II

${ }^{62}$ Ibidem, k. 49-50; A. Friszke, M. Zaremba, op. cit., s. 42.

${ }^{63}$ AAW, SPP, 04/34, Rada Główna Episkopatu Polski 1979, Sprawozdanie Bpa. Br. Dąbrowskiego z wykonania zadań w Rzymie zleconych mu przez prymasa Polski, 20 III 1979, k. $55-61$.

${ }^{64}$ Ibidem, k. 55; ibidem, Protokół Rady Głównej Episkopatu Polski z 20 III 1979, k. 64.

${ }^{65}$ Ibidem, Sprawozdanie Bpa. Br. Dąbrowskiego z wykonania zadań w Rzymie zleconych mu przez prymasa Polski, 20 III 1979, k. 55-57.

${ }^{66}$ Ibidem, k. 57; AAW, SPP, 04/297, Konferencja Plenarna Episkopatu Polski z 21-22 III 1979, Protokół Konferencji Plenarnej Episkopatu Polski z 21-22 III 1979, k. 30; A. Friszke, M. Zaremba, op. cit., s. 42.

${ }^{67}$ AAW, SPP, 04/34, Rada Główna Episkopatu Polski 1979, Sprawozdanie Bpa. Br. Dąbrowskiego z wykonania zadań w Rzymie zleconych mu przez prymasa Polski, 20 III 1979, k. 58; P. Raina, Wizyty..., s. 37-40. 
w czasie pobytu delegacji Episkopatu w Watykanie miało miejsce 16 marca. Ojciec Święty sprecyzował wtedy kilka istotnych kwestii związanych z pielgrzymką. Najważniejsza z nich to podkreślenie, iż program wizyty nie będzie już poszerzany, a jedynie uściślany. Ustalono również precyzyjnie kolejność działania: uzgodnienie programu z władzami, „naniesienie nieistotnych poprawek przez KPE" (w wymowny sposób w swoim sprawozdaniu bp Dąbrowski oddał właściwa rolę Konferencji Plenarnej Episkopatu, która zasadniczo potwierdzała tylko ustalenia podjęte przez RG, prymasa lub Jana Pawła II), zatwierdzenie przez papieża, równoczesne ogłoszenie programu w Watykanie i Warszawie ${ }^{68}$. Kolejnym istotnym ustaleniem, którego - jak warto dodać - trzymali się później polscy biskupi, było podkreślenie przez papieża: „W okresie do wizyty Papieża w Polsce musimy unikać wszyscy wystapień drażniących /konfrontacjil”69.

Następne posiedzenie RG odbyło się 20 marca, kilka dni po powrocie delegacji z Watykanu. W jego trakcie członkowie Rady zapoznali się z projektem programu wizyty przygotowanym przez współpracowników papieża, przy współudziale delegacji Episkopatu, i zatwierdzonym przez Jana Pawła II. Jak warto podkreślić, program nie został przyjęty bez zastrzeżeń. Metropolita poznański abp Jerzy Stroba przekonywał, iż do programu pielgrzymki należy włączyć Poznań, gdyż „Poznaniacy nie mogą zrozumieć dlaczego Ojciec Święty pominą ich miasto", on sam zaś otrzymuje wiele listów w tej sprawie. Ordynariusz poznański uważał, iż można by tak zmodyfikować plan wizyty, by Jan Paweł II odprawił nabożeństwo w Poznaniu 3 czerwca $^{70}$. Oponował przeciwko temu prymas Wyszyński, kierując się pod tym względem postanowieniem Ojca Świętego przekazanym delegacji Episkopatu w dniach 10-16 marca, iż nie należy dalej poszerzać programu ${ }^{71}$. Wsparli go bp Kaczmarek i Rozwadowski,

${ }^{68}$ AAW, SPP, 04/34, Rada Główna Episkopatu Polski 1979, Sprawozdanie Bpa. Br. Dąrowskiego z wykonania zadań w Rzymie zleconych mu przez prymasa Polski, 20 III 1979, k. 60; A. Friszke, M. Zaremba, op. cit., s. 43.

69 AAW, SPP, 04/34, Rada Główna Episkopatu Polski 1979, Sprawozdanie Bpa. Br. Dąrowskiego z wykonania zadań w Rzymie zleconych mu przez prymasa Polski, 20 III 1979, k. 60. Warto podkreślić, iż podobnie było w czasie dwóch kolejnych wizyt, gdy w okresie przygotowawczym do pielgrzymek biskupi starali się nie wchodzić w spory z władzami i równocześnie tonować ostre wystapienia duchownych (szczególnie tych związanych z opozycja). Szerzej zob. Operacja „Zorza II” Stużba Bezpieczeństwa i Komitet Wojewódzki PZPR wobec wizyty Jana Pawła II w Trójmieście (czerwiec 1987), red. nauk. S. Cenckiewicz, M. Kruk, Warszawa-Gdańsk 2008; Pielgrzymki Jana Pawła II...; R. Łatka, Polityka władz PRL..., s. 273-316, 391-423.

70 AAW, SPP, 04/34, Rada Główna Episkopatu Polski 1979, Protokół Rady Głównej Episkopatu Polski z 20 III 1979, k. 65-66.

${ }^{71}$ Ibidem, Sprawozdanie Bpa. Br. Dąbrowskiego z wykonania zadań w Rzymie zleconych mu przez prymasa Polski, 20 III 1979, k. 60; ibidem, Protokół Rady Głównej Episkopatu Polski z 20 III 1979, k. 65-66; AAW, SPP, 04/297, Konferencja Plenarna Episkopatu Polski z 21-22 III 1979, Protokół Konferencji Plenarnej Episkopatu Polski z 21-22 III 1979, k. 31-32. 
którzy „ustosunkowali się negatywnie do postulatów Poznania, bo podobne postulaty mogłyby wysunąć także Gdańsk i Łódź”72. Ostatecznie RG nie wprowadziła więc żadnych modyfikacji do ramowego programu wizyty, prymas zaś potwierdził modus procedendi w przygotowaniu wizyty:

- należy Polskę podzielić na rejony - Metropoliami

- w rozmowach z Władzami [sic!] uzgodnić szczegóły nawiedzenia miast

- Trzeba uzgodnić miejsca lądowania helikopterów, place na główne uroczystości, środki transportu dla Papieża i wiernych ${ }^{73}$.

Ostatnie przed przyjazdem Ojca Świętego spotkanie RG odbyło się 3 maja i miało nadzwyczajny charakter. Jego celem było ostateczne zatwierdzenie ramowego programu pielgrzymki. Odbywało się bez chorego kard. Wyszyńskiego, który jednakże zastrzegł sobie, iż „W razie spraw trudnych do uzgodnienia - Ksiądz Prymas prosi o ich przedłożenie sobie" ${ }^{4}$. W jednoznaczny sposób pokazuje to hierarchię w polskim Kościele, w którym prymas był „ostateczna instancją" Przebieg RG udowadnia również, kto zajmował kolejne pozycje w hierarchii: abp Macharski prowadzacy obrady i bp Dabrowski referujacy kwestię przygotowań do wizyty Jana Pawła $\mathrm{II}^{75}$. Sekretarz Episkopatu skupił się na przedstawieniu trudności i warunków, jakie władze stawiały odnośnie do programu wizyty ${ }^{76}$. RG, jak wynika z protokołu, po krótkiej dyskusji ustaliła, iż należy szybko uzgodnić i opublikować program wizyty, tak by móc go odczytywać w czasie nabożeństw majowych. Zdecydowano się w związku z tym na szereg ustępstw, które postulowała strona partyjna. Wynikały one $\mathrm{w}$ zasadniczej mierze $\mathrm{z}$ obawy, iż dalsze odkładanie ogłaszania programu przyczyniłoby się do dezorientacji społeczeństwa, a jak zauważali biskupi, „społeczeństwo zdezorientowane jest podatne na plotki i łatwo się demobilizuje"77. Z tego też względu biskupi zgodzili się, by spotkanie z władzami PRL odbyło się w Belwederze, a nie na Zamku Królewskim; przenieść spotkanie z młodzieżą z 3 czerwca na inne miejsce; skrócić spotkanie z młodzieżą na Wzgórzu Lecha w Gnieźnie; przenieść nabożeństwo dla diecezji częstochowskiej z os. Tysiaclecia na inne miejsce oraz

72 AAW, SPP, 04/34, Rada Główna Episkopatu Polski 1979, Protokół Rady Głównej Episkopatu Polski z 20 III 1979, k. 65.

${ }^{73}$ Ibidem, k. 66; AAW, SPP, 04/297, Konferencja Plenarna Episkopatu Polski z 21-22 III 1979, Protokół Konferencji Plenarnej Episkopatu Polski z 21-22 III 1979, k. 32.

${ }^{74}$ AAW, SPP, 04/34, Rada Główna Episkopatu Polski 1979, Protokół Rady Głównej Episkopatu Polski z 3 V 1979, k. 67; P. Raina, Kardynat Wyszyński. Czasy prymasowskie $1979 \ldots$, s. $62-63$.

75 AAW, SPP, 04/34, Rada Główna Episkopatu Polski 1979, Protokół Rady Głównej Episkopatu Polski z 3 V 1979, k. 67-69.

${ }^{76}$ A. Friszke, M. Zaremba, op. cit., s. 45-51.

77 AAW, SPP, 04/34, Rada Główna Episkopatu Polski 1979, Protokół Rady Głównej Episkopatu Polski z 3 V 1979, k. 68. 
- aby przyjać do wiadomości nie wyrażenie zgody Władz Państwowych [sic!] na spotkanie z wiernymi w Trzebnicy/Wrocławiu/ i urządzić nabożeństwo dla Dolnego i Opolskiego Śląska w Częstochowie;

- aby przyjać do wiadomości nie wyrażenie zgody Władz Państwowych [sic!] na spotkanie z robotnikami w Piekarach i zorganizowania nabożeństwa dla robotników Górnego Śląska i Zagłębia Dąbrowskiego w Częstochowie ${ }^{78}$.

Jak jednoznacznie wynika z protokołu RG z 3 maja, to właśnie ona zadecydowała o ostatecznym kształcie pielgrzymki, dla jej dobrej organizacji rezygnując z niektórych punktów programu. Równocześnie jej członkowie zajęli krytyczne stanowisko wobec prac Kościelnego Komitetu Koordynacyjnego, zauważając, iż nie tylko społeczeństwo nie zostało doinformowane w kwestii pielgrzymki, ale również duchowieństwo oraz nawet „biskupi diecezjalni

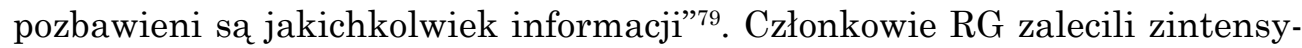
fikowanie prac Komitetu i przygotowanie do 10 maja materiałów, wskazań duszpasterskich i haseł modlitewnych na okres pielgrzymki. Polecono również Sekretariatowi Episkopatu sporządzenie dokumentacji dotyczącej stawianych przez władze regionalne ograniczeń dla chcących wziąć udział w nabożeństwach w czasie wizyty Jana Pawła II ${ }^{80}$. Protokół RG z 3 maja jasno pokazuje, że zorganizowanie pierwszej pielgrzymki było dla strony kościelnej niełatwym przedsięwzięciem i że na miesiąc przed wizytą Ojca Świętego nie brakowało rozmaitych trudności o charakterze organizacyjnym. Udowadnia również, iż nie wszystkie decyzje w związku z pielgrzymką konsultowano ze Stolica Apostolską i samym papieżem, który jedynie wyznaczył ramy programu, podczas gdy RG dokonywała szczegółowych rozstrzygnięć.

\section{Jan Paweł II i prymas Wyszyński w czasie Rady Głównej z 5-6 czerwca ${ }^{81}$}

Zgodnie z założonym wcześniej programem w posiedzeniu RG na Jasnej Górze $\mathrm{w}$ czasie pielgrzymki wziął udział Jan Paweł $\mathrm{II}^{82}$. Odbyło się ono w dniach

78 Ibidem, k. 68.

${ }^{79}$ Ibidem, k. 68.

${ }^{80}$ Ibidem, k. 68-69.

${ }^{81}$ Należy podkreślić, iż kard. Wojtyła po swoim wyborze na papieża w dalszym ciąu uważał się za członka Episkopatu Polski. AAW, SPP, 04/295, Konferencja Plenarna Episkopatu Polski, Protokół Konferencji Plenarnej Episkopatu Polski z 28 i 29 XI 1979, k. 47.

${ }^{82} \mathrm{~W}$ dokumentacji RG znajdują się dwa zapisy przebiegu tego posiedzenia. Pierwszy z nich, w postaci wykonanego prawdopodobnie na bieżąco stenogramu, liczy 27 stron, drugi zaś to sporządzony później protokół liczący 23 strony, co do meritum nie ma w nich jednak istotnych różnic. AAW, SPP, 04/34, Rada Główna Episkopatu Polski 1979, Summa Pontifici. Wypowiedzi na Radzie Głównej Episkopatu Polski, 5 VI 1979, k. 71-96; ibidem, Protokół Rady Głównej Episkopatu Polski z 5 VI 1979, k. 98-120. Jan Paweł II uczestniczył również w Konferencji Plenarnej, która odbyła się w dniach 5-6 czerwca. AAW, SPP, 04/298, Konferencja Plenarna Episkopatu Polski z 5-6 VI 1979, Protokół z Konferencji Plenarnej 
5-6 czerwca. Jego przebieg jest niezwykle istotny, gdyż doskonale obrazuje koncepcje stosunków państwo-Kościół w PRL, a szerzej - roli Kościoła katolickiego w całym bloku wschodnim. Dyskusja koncentrowała się wokół wymiany zdań Ojca Świętego i kard. Wyszyńskiego, które uzupełniły spostrzeżenia bpa Dąbrowskiego i (w mniejszym stopniu) innych członków Rady. W tym miejscu skoncentruję się na przedstawieniu tych wątków, gdyż maja one niewatpliwie kluczowe znaczenie dla zrozumienia polityki prowadzonej przez Stolicę Apostolska pod kierownictwem Jana Pawła II oraz sposobu funkcjonowania polskiego Kościoła w realiach Polski „ludowej” (ocena pielgrzymki zostanie omówiona w osobnej części). Warto również dodać, iż Rada zebrała się na specjalne życzenie papieża, który chciał wysłuchać zdania jej członków na tematy związane nie tylko z bezpośrednim funkcjonowaniem Kościoła na ziemiach polskich ${ }^{83}$. Ojciec Święty na początku swojej wypowiedzi podkreślił miejsce Polski w świecie, światowy charakter wydarzeń, które się w niej rozgrywały, oraz wielki autorytet jej prymasa ${ }^{84}$. Zwracał uwagę na trudności związane z pielgrzymką do Ojczyzny. Wskazywał ponadto, jakich argumentów należy używać $\mathrm{w}$ rozmowach $\mathrm{z}$ władzami na temat wizyty: „my stale mamy jeden wielki argument: Pamiętajcie Panowie, że Papież przyjeżdżając tu, ryzykuje więcej, niż Wy w obliczu całego świata. Bo ryzykuje to, że da wam alibi, na które wy nie zasługujecie. Tak im trzeba mówić w całości" ${ }^{85}$. Równocześnie Jan Paweł II zaznaczył, iż nie było w tamtym czasie alternatywy dla władz politycznych w kraju i dobrze, „żeby rządzili przynajmniej tacy, jak Pan Gierek" ${ }^{86}$. W odpowiedzi prymas Wyszyński, wracając do rozmowy z I sekretarzem PZPR ze stycznia 1979 r.,

Episkopatu Polski 5 i 6 VI 1979, k. 7-25. Zob. też treść przemówienia Jana Pawła II do Konferencji Plenarnej: AAW, SPP, 04/299, Konferencja Plenarna Episkopatu Polski z 5-6 IX 1979, Przemówienie Ojca Świętego Jana Pawła II w Częstochowie na Konferencji Plenarnej Episkopatu Polski, 5 VI 1979, k. 29-52.

${ }^{83} \mathrm{Na}$ początku posiedzenia Jan Paweł II podkreślił: „Tęsknię za stylem pracy Rady Głównej. [...] Bardzo mnie raduje i pociaga swobodna wymiana myśli. Byłbym bardzo wdzięczny [...] gdybyście zechcieli powiedzieć Papieżowi co myślicie i czujecie”. AAW, SPP, 04/34, Rada Główna Episkopatu Polski 1979, Protokół Rady Głównej Episkopatu Polski z 5 VI 1979, k. 98.

84 Jak zaznaczał w dalszej części swojej wypowiedzi: „Pamiętajcie, że Kościół polski ma pozycję światową czy chce czy nie chce. Fakt, że papieża wybrali z Polski, jest tylko dowodem na to. W myśleniu Kościoła w Polsce ma być stale obecny ten problem: dlaczego doświadczenia Kościoła w Polsce stały się potrzebne całemu Kościołowi? Kościół w Polsce stał się i staje się wciąż potrzebny i to w wymiarach uniwersalnych - na południe, na północ, wszędzie”. Ibidem, k. 101-102.

${ }^{85}$ Ibidem, k. 100.

${ }^{86}$ Ibidem, k. 102. Zob. też: P. Raina, Kardynat Wyszyński. Czasy prymasowskie 1979..., s. 95-96. Należy w tym miejscu dodać, iż pozytywny stosunek do Gierka miał również prymas Wyszyński, szczególnie jak się go porówna z jego opinią na temat Władysława Gomułki. Szerzej zob. Z. Zieliński, Kościół w kręgu rzeczywistości politycznej, Lublin 2003, s. $174-175$. 
zauważył, iż „ujawnił on swoją troskę o Polskę. Więc jakiś element zrozumienia jest" ${ }^{\prime 7}$. Polski papież $\mathrm{w}$ rozmowie prowadzonej na posiedzeniu RG wracał również do kwestii normalizacji relacji państwo-Kościół, wskazał też, iż nadszedł odpowiedni moment ustalenia relacji Stolica Apostolska-Polska „ludowa”88.

Jan Paweł II w czasie obrad poruszył także problematykę sposobu funkcjonowania Stolicy Apostolskiej oraz jej polityki, a szczególnie roli nuncjusza apostolskiego w kontekście polskiego Kościoła i roli abpa Poggiego. Prosił o opinię członków RG, nadmieniając:

mnie by chodziło o odpowiedź, czy kontynuować to w tej samej postaci, to znaczy z tymi samy ludźmi. Bo - myślę tutaj głośno - jeszcze o tym nie rozmawiałem z Casarolim, chociaż zaczynałem z nim tą rozmowę kilkakrotnie. Na pewno on też się godzi z tym, że Poggi jest przeładowany tymi zadaniami: Węgry, Czechosłowacja, Rumunia. Właściwie ta Polska w jego funkcjach jest trochę piątym kołem $\mathrm{u}$ wozu. Bo jest to w ogóle problem za duży, a po drugie - przy tych wszystkich innych, które on ma, z jego usposobieniem drobiazgowym i przy tym, że tutaj sytuacja jest jaka jest, że właściwie panem sytuacji jest Episkopat, że właściwym reprezentantem interesów Stolicy Apostolskiej to znaczy Kościoła na tym szczeblu i właściwym rzecznikiem spraw Kościoła wobec władz państwowych - jest Ksiądz Prymas i Episkopat - on czuje się zagubiony. [...] Byłbym bardzo rad usłyszeć - nie koniecznie dzisiaj - ale w jakiejś perspektywie niedalekiej - pewne sugestie na ten temat. Te sugestie są mi potrzebne, żeby sprawę po prostu ustawić w jakiś nowy, właściwszy sposób ${ }^{89}$.

Z odpowiedzia na kwestie poruszone przez Jana Pawła II nie zwlekał prymas, który od razu odniósł się do problematyki funkcjonowania nuncjuszów, nie tylko zresztą w polskim kontekście. Zauważał, iż należy ich w inny sposób szkolić, tak by znali specyfikę państw, w których pełnią swoja misję. Kardynał Wyszyński zwracał uwagę, iż w polskim Kościele abp Poggi „jest skończony”, gdyż zamiast pełnić swoją misję, zbierał informacje poza Episkopatem. Mimo to uważał, że nie należy go odwoływać, gdyż byłoby to „załamaniem się jakiejś linii” w relacjach z władzami, z tego względu

${ }^{87}$ AAW, SPP, 04/34, Rada Główna Episkopatu Polski 1979, Protokół Rady Głównej Episkopatu Polski z 5 VI 1979, k. 104.

${ }^{88}$ Ibidem, k. 104; ibidem, S. Wyszyński, Problemy do rozważania przez Radę Główną i Konferencję Plenarną Episkopatu Polski, 1 IX 1979, Choszczówka, k. 161-162; ibidem, Załącznik do opracowania „Problemy do rozważania przez Radę Główną i Konferencję Plenarną Episkopatu Polski. Normalizacja w wypowiedziach Ojca Świętego”, oprac. ks. A. Orszulik, 30 VIII 1979, Warszawa, k. 169-176; J. Żaryn, Dzieje Kościoła..., s. 410-412; P. Raina, Kardynat Wyszyński. Czasy prymasowskie 1979..., s. 111. Analogiczne stanowisko Jan Paweł II przedstawił w czasie obrad Konferencji Plenarnej: AAW, SPP, 04/299, Konferencja Plenarna Episkopatu Polski z 5-6 IX 1979, Przemówienie Ojca Świętego Jana Pawła II w Częstochowie na Konferencji Plenarnej Episkopatu Polski, 5 VI 1979, k. 40-45.

${ }^{89}$ AAW, SPP, 04/34, Rada Główna Episkopatu Polski 1979, Protokół Rady Głównej Episkopatu Polski z 5 VI 1979, k. 112. 
należałoby w przekonaniu prymasa „mniej się nim posługiwać na terenie Polski" ${ }^{90}$. Jan Paweł II nie tylko - jak wynika z protokołu - zaakceptował tę sugestię, ale również podkreślił, że w przyszłości można by Poggiego odwołać ze stanowiska ${ }^{91}$. Kardynał Wyszyński podczas rozmowy zaznaczał ponadto, że nie należy ustępować władzom PRL w sprawie postulatu uzyskania osobowości prawnej przez Kościół oraz jak dodawał: „mnie się wydaje, że trzeba podtrzymywać stosunki, one moga być życzliwe, nie moga być za bardzo, żeby nie wprowadzać w błąd opinii publicznej, ale zrywać też nie myślę"92. Tego typu przekonaniem w relacjach z władzami prymas kierował się aż do swojej śmierci, a jego linię pod tym względem starał się kontynuować kard. Józef Glemp ${ }^{93}$. Najtrafniej stosunek władz do rozmów z Kościołem przedstawił bp Dąbrowski, który zauważył: „Im zależy na Kościele, bo Kościół jest siła. W tej chwil uznali Kościół za partnera. Stolica Apostolska i Kościół to siła, z którą trzeba się liczyć. Dlatego nie chcieliby zrywać stosunków, ale nie chcieliby też dawać Kościołowi jakiś większych uprawnień” ${ }^{4}$. Z tego względu, jak zaznaczał sekretarz Episkopatu, odnosząc się do Jana Pawła II:

Trzeba by trzymać urzędników watykańskich, żeby nie szli na cokolwiek, lub nie na pozory tylko. Linia musi być jasna. Komunistom zależy na tym, żeby z Kościołem była zgoda, bo nie są siebie zbyt pewni. Komunistów nie stać na to, żeby zerwać z Kościołem. Watykan nie może sobie pozwolić na żadne pozory. Trzeba sprawę stawiać jasno i zawsze z Episkopatem - wtedy wyjdzie dobrze ${ }^{95}$.

Ojciec Święty zgadzał się z tym rozumowaniem, podkreślając, że liczy się tylko pełna normalizacja, a nie żadne półprodukty czy produkty zastępcze, oraz podkreślał: „[...] raczej należy wyczekać z inicjatywa, aż im będzie na tym zależeć, aż oni przyjmą wszystkie warunki. Taki jest wniosek" ${ }^{96}$. $\mathrm{Z}$ tego wniosku wynikała postawa Kościoła w latach osiemdziesiątych wobec

${ }^{90}$ Ibidem, k. 112-114. Analogiczną opinię przedstawił bp Dąbrowski, który dodawał również, że „Kąkol się bawi Poggim”. Ibidem, k. 115. Zob. też: ibidem, Problemy do rozważania przez Radę Główną i Konferencję Plenarną Episkopatu Polski, 2 IX 1979 Choszczówka, k. 163. Członkowie RG w swoim liście do Jana Pawła II z października 1979 r. wskazywali, iż pod kierunkiem abpa Poggiego, jako kierownika zespołu Stolicy Apostolskiej ds. roboczych kontaktów z władzami, proces normalizacji nie zdoła zostać posunięty na przód. Ibidem, Pismo Rady Głównej Episkopatu Polski do Jana Pawła II z 11 X 1979, k. 301.

${ }^{91}$ Ibidem, Protokół Rady Głównej Episkopatu Polski z 5 VI 1979, k. 118.

${ }_{92}$ Ibidem, k. 114.

${ }_{93}$ M. Kindziuk, Kardynat Józef Glemp. Ostatni taki prymas, Warszawa 2010, s. 130-294; K. Michalski, Działalność Komisji Wspólnej przedstawicieli Rzadu PRL i Episkopatu Polski 1980-1989, Warszawa 2012; R. Łatka, Polityka władz PRL..., s. 162-170.

${ }^{94}$ AAW, SPP, 04/34, Rada Główna Episkopatu Polski 1979, Protokół Rady Głównej Episkopatu Polski z 5 VI 1979, k. 115.

${ }^{95}$ Ibidem, k. 116.

${ }^{96}$ Ibidem, k. 116-117. 
unormowania relacji na linii Stolica Apostolska-PRL oraz ustawy o osobowości prawnej Kościoła ${ }^{97}$.

Prymas Wyszyński wiele uwagi poświęcił również postawie władz wobec pielgrzymki, podkreślając występowanie rozmaitych frakcji w PZPR w kwestii wizyty Jana Pawła II. Wskazywał na grupę promoskiewska, która miała nadzieję, że „to rozłoży ostatecznie p. Gierka, który się zaangażował w tej dziedzinie" ${ }^{98}$. Ponadto prymas zwracał uwagę na wzmocnienie Kościoła w całym bloku wschodnim, obudzenie się Litwy, Łotwy, Estonii, Białorusi, Ukrainy i tych katolików, którzy żyją w świecie wschodnim. Stwierdzał:

Obecność Papieża w państwie bloku jest jakimś przełamaniem żelaznej kurtyny w bloku. [...] Gdyby nie doszło do wizyty - Kościół by sobie to wytłumaczył, wzmocniłby się i pracował dalej, ale te nadzieje zwłaszcza Litwy, Łotwy? Ci ludzie potrzebuja podtrzymania. Obecność Ojca Świętego tutaj w Polsce jest wzrostem nadziei, jakiejś duchowej mobilizacji, ożywienia wiary w tych ludziach, że jednak można coś zrobić zajmując zdecydowana postawęe

Analogiczną ocenę wyraził bp Ignacy Tokarczuk, który silnie akcentował, iż wizyta Jana Pawła II była niezwykle istotna z punktu widzenia Ostpolitik. Wskazywał na entuzjazm i nadzieję narodów wschodnich, najpierw w związku z wyborem polskiego papieża, a później z jego przyjazdem do jednego z państw bloku ${ }^{100}$.

Jak pokazuje protokół z posiedzenia RG z udziałem Jana Pawła II, miało ono niezwykle istotne, można nawet powiedzieć - strategiczne znaczenie. Nie tylko wyciagnięto wnioski z przyjazdu Ojca Świętego do Ojczyzny, ale również rozmawiano o taktyce Kościoła i jego podejścia do władz, strategii, która jak jasno wynika z wydarzeń lat 1979-1989 - była realizowana w praktyce.

\section{Oceny przebiegu i efektów pielgrzymki}

Polscy biskupi, duchowieństwo i wierni oceniali zgodnie wizytę Jana Pawła II jako fakt niezwykle doniosły i znaczący sukces Kościoła. Pierwsze jej oceny

${ }_{97}$ Szerzej zob. K. Michalski, op. cit.; R. Łatka, Droga do ustawowego uregulowania osobowości prawnej Kościoła katolickiego w Polsce „ludowej”, „Colloquium Wydziału Nauk Humanistycznych i Społecznych” 2015, nr 4, s. 99-126; idem, Priorytety polityki wyznaniowej władz PRL $w$ latach osiemdziesiatych, w: Priorytety polityki..., s. 307-332.

${ }_{98}$ AAW, SPP, 04/34, Rada Główna Episkopatu Polski 1979, Protokół Rady Głównej Episkopatu Polski z 5 VI 1979, k. 103.

${ }^{99}$ Ibidem, k. 104. Należy podkreślić, iż na niezwykle istotny efekt ożywienia Kościoła katolickiego w państwach bloku wschodniego na skutek pielgrzymki Jana Pawła II wskazywało wielu badaczy. Szerzej zob. J. Żaryn, Dzieje Kościoła..., s. 418; G. Weigel, Świadek nadziei. Biografia papieża Jana Pawła II, tłum. M. Tarnowska i in., Kraków 2012, s. 409-412.

100 AAW, SPP, 04/34, Rada Główna Episkopatu Polski 1979, Protokół Rady Głównej Episkopatu Polski z 5 VI 1979, k. 109-110. 
w gronie członków Episkopatu pojawiły się już na posiedzeniu RG 5 VI 1979 r., a więc jeszcze w czasie trwania samej pielgrzymki. Prymas podkreślił:

Na pewno wszyscy się ciesza, na pewno wszyscy uważają to za jakieś zwycięstwo. Może treść tego zwycięstwa ustawiają na płaszczyźnie narodowo-politycznej. Może to jeszcze nie jest dla wielu ludzi zwycięstwo natury religijnej, zwycięstwo prawdy Bożej, zwycięstwo interwencji Bożej, tak jak mi się to wydawało w związku z nabożeństwem na Placu Zwycięstwa, które było na pewno zwycięstwem Palca Bożego ${ }^{101}$.

Kardynał Wyszyński wracał także do spotkania z Gierkiem 29 V 1979 r., gdy jego rozmówca podkreślił, iż sam na pielgrzymce nic nie zyska, a wręcz przeciwnie, gdyż do walki z nim mobilizuja się jego przeciwnicy w partii, którzy zarzucać mu będa „klerykalizację Polski” na skutek pielgrzymki ${ }^{102}$. Prymas wskazywał również, że rząd po pielgrzymce będzie przez jakiś czas milczał, gdyż musi się naradzić w swoim gronie i pojechać po instrukcje do Moskwy ${ }^{103}$. Należy w tym miejscu dodać, iż wśród materiałów pomocniczych do posiedzenia RG z 26 czerwca znalazł się dokument poświęcony naradzie władz Polski „ludowej” z przedstawicielami KPZR w Moskwie, która miała się odbyć między 26 a 28 V 1979 r. i w czasie której jednym z tematów były relacje państwo-Kościół w PRL ${ }^{104}$. Wnioski, jakie miały wypływać z tego dokumentu, sprowadzały się do polecenia, by „polscy towarzysze” wytrzymali presję Kościoła i nie zgadzali się na ustępstwa, których domagają się polscy biskupi (przyznanie osobowości prawnej, tworzenie organizacji kościelnych, zgoda na obecność Kościoła w TV). Ponadto delegaci władz KPZR mieli zauważyć, iż przyjazd Jana Pawła II wywołał zafascynowanie jego postacią i ożywienie religijne w takich państwach, jak NRD, Czechosłowacja, Węgry, Ukraina, Białoruś i Litwa. Sugerowano dalszą walkę z wpływami społecznymi Kościoła:

a jeśli nie możecie tego zrobić, to uwikłajcie Kościół w zagadnienia globalne: walkę o pokój, w walkę o sprawiedliwość społeczną na całym świecie, likwidację skutków

101 Ibidem, k. 105.

102 Ibidem, k. 104. W roboczej wersji przebiegu RG z 5 czerwca pojawiło się określenie wskazujące, iż głównym przeciwnikiem, którego w rozmowie z prymasem miał na myśli Gierek, był Wojciech Jaruzelski. Dodawał, iż to prawdopodobnie jego oponenci w partii odpowiadali za utrudnienia komunikacyjne w terenie w czasie pielgrzymki. Ibidem, Summa Pontifici. Wypowiedzi na Radzie Głównej Episkopatu Polski, 5 VI 1979, k. 77-78.

${ }^{103}$ Ibidem, Protokół Rady Głównej Episkopatu Polski z 5 VI 1979, k. 106. Jego opinię uzupełnia wypowiedź abpa Stroby, który podkreślał, iż być może władze partyjne zdyskontują wizytę Jana Pawła II, by zmniejszyć swoje uzależnienie od Moskwy. Równocześnie dodawał, iż prawdopodobnie „będą próbowali montować jakąś kontrakcję ideologiczna”, żeby nie utrwaliły się pozytywne efekty pielgrzymki w postaci uzyskania podmiotowości przez społeczeństwo. Ibidem, k. 106-107.

104 Autorem dokumentu, zgodnie z zapiskami prymasa, był Kukołowicz. P. Raina, Kardynat Wyszyński. Czasy prymasowskie 1979..., s. 104. 
imperializmu i kolonializmu, w walkę o całkowite rozbrojenie, i tyle, tyle innych akcji. [...] Niech swoje siły tam wyczerpię i dynamikę wytraci. [...] A Jana Pawła II Wy nie lekceważcie, bo on może nam wiele jeszcze napsuć ${ }^{105}$.

Trudno orzec, kto przekazał doradcy prymasa Kukołowiczowi informacje na temat tej narady, jaka pozycję we władzach PZPR zajmował i jakimi motywacjami się kierował, niemniej zakładając, iż spotkanie w Moskwie miało taki przebieg, jak przedstawiano to w tym materiale, to należy właśnie w nim poszukiwać źródeł usztywnienia polityki władz PRL wobec Kościoła, do jakiego doszło po wyjeździe Jana Pawła II.

Najszerzej efekty pielgrzymki członkowie RG przedstawili na jej posiedzeniu 26 czerwca. Ich spojrzenie miało wielowątkowy charakter, w przeciwieństwie do analiz władz, które koncentrowały się w zasadniczej mierze na trzech aspektach: wpływie pielgrzymki na sytuację społeczno-polityczną Polski „ludowej”, wzroście pozycji polskiego Kościoła oraz wpływie na relacje państwo-Kościół ${ }^{106}$. Nie oznacza to bynajmniej, iż pewne oceny władz partyjnych i RG Episkopatu nie pokrywały się, szczególnie jeśli chodzi o wnioski stwierdzajace wzrost wpływów społecznych Kościoła. W tym miejscu skupimy się na opisie spotkania Komisji Mieszanej z 25 VI 1979 r., w czasie której przedstawiono najwięcej zbieżnych wniosków odnośnie do efektów pielgrzymki. Z tego względu konieczne jest omówienie tego spotkania z perspektywy członków RG, tym bardziej że ze strony przedstawicieli władz było to raczej „robienie dobrej miny do złej gry”. Przebieg posiedzenia Komisji Mieszanej zreferowali na posiedzeniu RG bp Dąbrowski i kard. Macharski ${ }^{107}$. Ten pierwszy podkreślił, iż obie strony były zgodne co do sukcesu wizyty, ale równocześnie zaznaczył przedstawicielom władz, iż w późniejszym terminie przedstawi spis zastrzeżeń i interwencji Kościoła w sprawie „osób dyskryminowanych”. Zasugerował również, że najważniejsze problemy w relacjach państwo-Kościół, takie jak: status prawny Kościoła, budownictwo sakralne, obsada stanowisk kościelnych, cenzura czy wychowanie młodzieży a laicyzacja, można by rozwiązać komisyjnie, nawiązując do dobrej współpracy w Komisji organizacyjnej pielgrzymki. Kania, jak relacjonował dalej bp Dąbrowski, podzielił jego opinię na temat pozytywnych efektów wizyty, ale nie zgodził się na przekazanie do Komisji

105 AAW, SPP, 04/34, Rada Główna Episkopatu Polski 1979, Papież w Polsce. Narada. Rada Główna, 26 VI 1979, k. 123-126. Warto dodać, że prymas zauważył, iż władze jako jeden z efektów wizyty traktowały umocnienie wspólnej z Kościołem walki o pokój. Ibidem, Protokół Rady Głównej Episkopatu Polski z 4 IX 1979, k. 278.

${ }^{106}$ Na ten temat szerzej zob. Wstępna ocena przebiegu wizyty Jana Pawła II, zachowań społecznych i treści przemówień papieża opracowana w Wydziale Pracy Ideowo-Wychowawczej KC PZPR w czerwcu 1979 r., w: Wizyta Jana Pawta II..., s. 259-271; Sprawozdanie z działań Ministerstwa Spraw Wewnętrznych związanych z pobytem w Polsce Jana Pawła II, w: Wizyta Jana Pawła II..., s. 272-297; A. Friszke, M. Zaremba, op. cit., s. 67-73.

107 AAW, SPP, 04/34, Rada Główna Episkopatu Polski 1979, Protokół Rady Głównej Episkopatu Polski z 26 VI 1979, k. 128-130. 
Mieszanej problematyki, której podjęcie sugerował sekretarz Episkopatu ${ }^{108}$. Kardynał Macharski akcentował z kolei szczerość Kani, jeśli chodzi o ocenę „patriotyzmu Ojca Świętego”, i zwracał uwagę, że stanowisko przedstawicieli władz w kwestii postulatów Kościoła oznacza „odsunięcie się od koncepcji kontynuowania jakiekolwiek Komisji Wspólnej”"109. W tej ostatniej kwestii metropolita krakowski miał całkowitą rację, gdyż powrót do idei Komisji Wspólnej nastapił dopiero na skutek wydarzeń Sierpnia ' $80^{110}$.

Ocenę pielgrzymki członkowie Rady przedstawili na posiedzeniach w czerwcu i wrześniu 1979 r. Nie ma potrzeby omawiać ich osobno, wydobędę raczej ich wspólne wątki, tak by możliwie całościowo ukazać, w jaki sposób Rada oceniła efekty wizyty Jana Pawła II w Ojczyźnie. Generalna, niezwykle pozytywną ocenę pielgrzymki przedstawiono również na konferencji biskupów ordynariuszów 5 września, gdzie jednoznacznie stwierdzono: „Mimo wielu trudności obiektywnych oceniliśmy pielgrzymkę Ojca Świętego jako wydarzenie wyjątkowe, historyczne, wysoko konstruktywne dla naszej pracy w Polsce"111.

Wiele uwagi na obu wspomnianych posiedzeniach RG poświęcono ocenie kościelnych przygotowań do wizyty. Warto podkreślić, iż nie szczędzono krytycznych słów, jeśli chodzi o funkcjonowanie struktur Kościoła zajmujących się organizowaniem pielgrzymki. Istotne znaczenie pod tym względem miały późne ogłoszenie programu wizyty i pewien chaos związany z programem duszpasterskim ${ }^{112}$. Jak podkreślał kard. Wyszyński: „wiele niedociagnięć było, na skutek tego żeśmy za długo rozmawiali”"113. Ponadto w przekonaniu przywódcy polskiego Kościoła nie wszędzie intensywnie manifestowano obecność Jana Pawła II, były diecezje, gdzie „nie wypadło to zbyt okazale” ${ }^{114}$. Niemniej

108 Ibidem, k. 128-129.

${ }^{109}$ Ibidem, k. 129-130.

110 Szerzej zob. K. Michalski, op. cit., s. 18-27; R. Łatka, Obraz opozycji w czasie rozmów Komisji Wspólnej Przedstawicieli Rzqdu PRL i Episkopatu Polski w latach 1980-1983, $\mathrm{w}$ : Miejsce i rola opozycji $w$ systemach autorytarnych i demokratycznych, red. K. Kowalik, M. Kluzik, Kraków 2013, s. 43-45.

111 AAW, SPP, 04/299, Konferencja Plenarna Episkopatu Polski z 5-6 IX 1979, Protokół z konferencji księży biskupów ordynariuszów dnia 5 IX 1979, k. 63.

112 AAW, SPP, 04/34, Rada Główna Episkopatu Polski 1979, Protokół Rady Głównej Episkopatu Polski z 26 VI 1979, k. 130-132. Jak wskazywał bp Pylak, część działań Kościoła była wyraźnie spóźniona, brakowało również centralnego, jednolitego programu duszpasterskiego. Ibidem, k. 137. Podobne zastrzeżenia zgłaszał abp Stroba. Ibidem, k. 138. Zob. też: ibidem, S. Wyszyński, Uwagi i obserwacje po pobycie Ojca św. Jana Pawła II w Polsce, VIII 1980, k. 252; AAW, SPP, 04/299, Konferencja Plenarna Episkopatu Polski z 5-6 IX 1979, Protokół 170 Konferencji Plenarnej Episkopatu Polski, Warszawa, 5 i 6 IX 1979, k. 74-75.

113 AAW, SPP, 04/34, Rada Główna Episkopatu Polski 1979, Protokół Rady Głównej Episkopatu Polski z 26 VI 1979, k. 139. Zob. też: P. Raina, Kardynat Wyszyński. Czasy prymasowskie $1979 \ldots$, s. $101-102$.

114 AAW, SPP, 04/34, Rada Główna Episkopatu Polski 1979, S. Wyszyński, Uwagi i obserwacje po pobycie Ojca św. Jana Pawła II w Polsce, VIII 1980, k. 252. 
jednak prymas generalnie wysoko ocenił działalność Komitetu Koordynacyjnego i jego lokalnych odpowiedników, wskazując na ich dużą sprawnośćc ${ }^{115}$.

Członkowie RG zwracali uwagę na fakt, iż władze nie miały wyjścia i musiały zgodzić się na przyjazd Jana Pawła II do Ojczyzny ${ }^{116}$. Najtrafniej poglądy tego gremium wyraził bp Tokarczuk, który podkreślił:

Gdy chodzi o zgodę władz na przyjazd Ojca Świętego, to uważam, że władze były w jakiejś sytuacji konieczności. Gdyby Ojciec Święty nie był Polakiem, łatwiejsza by była dla nich sytuacja, mogliby nie wyrazić zgody. Natomiast, gdy Polak został Papieżem, w tej sytuacji niewpuszczenie go do Ojczyzny, byłoby dla nich większym niebezpieczeństwem, jeszcze większym złem, aniżeli wpuszczenie. I dlatego jakiś zimny rachunek, jakaś konieczność tutaj zadecydowały ${ }^{117}$.

Współpracę z władzami pod wieloma względami oceniono jako dobra, szczególnie jeśli chodzi o władze centralne ${ }^{118}$ i Kraków ${ }^{119}$, niemniej biskupi mieli w pamięci rozmaite utrudnienia, stosowane przez władze wojewódzkie, których zarówno w czasie przygotowań, jak i samej pielgrzymki nie brakowało $^{120}$. Prymas polecił w zwiąku z tym opracowanie ich wykazu

${ }_{115}$ Ibidem, Rada Główna Episkopatu Polski 1979, Protokół Rady Głównej Episkopatu Polski z 26 VI 1979, k. 132; ibidem, S. Wyszyński, Uwagi i obserwacje po pobycie Ojca św. Jana Pawła II w Polsce, VIII 1980, k. 252; P. Raina, Kardynał Wyszyński. Czasy prymasowskie $1979 \ldots$, s. 104.

116 AAW, SPP, 04/34, Rada Główna Episkopatu Polski 1979, Protokół Rady Głównej Episkopatu Polski z 26 VI 1979, k. 135-149.

117 Ibidem, k. 135. Należy podkreślić, iż Gierek zgodę na przyjazd Jana Pawła II do Ojczyzny motywował właśnie polskim obywatelstwem papieża. A. Friszke, M. Zaremba, op. cit., s. 37-38. Por. M. Rakowski, op. cit., s. 42.

118 Arcybiskup Stroba wskazywał na dużą dojrzałość i odwagę władz centralnych (szczególnie w kontekście reakcji na pielgrzymkę państw ościennych). AAW, SPP, 04/34, Rada Główna Episkopatu Polski 1979, Protokół Rady Głównej Episkopatu Polski z 26 VI 1979, k. 137-138. Por. z oceną sformułowaną przez władze: Wstępna ocena przebiegu wizyty Jana Pawła II, zachowań społecznych i treści przemówień papieża opracowana w Wydziale Pracy Ideowo-Wychowawczej KC PZPR w czerwcu 1979 r., w: Wizyta Jana Pawła II..., s. 261.

119 AAW, SPP, 04/34, Rada Główna Episkopatu Polski 1979, Protokół Rady Głównej Episkopatu Polski z 26 VI 1979, k. 132-134. Jak podkreślał kard. Macharski: „W Krakowie, prezydent miasta P. Barcikowski postawił na swoim i dopilnował tego, żeby spotkania odbyły się w atmosferze życzliwości MO i służby bezpieczeństwa - z nami”. Ibidem, k. 133. Wydaje się, że w efektach tej współpracy z władzami przy organizacji pielgrzymki można się doszukiwać źródeł dobrych relacji metropolity krakowskiego z władzami wojewódzkimi w latach osiemdziesiątych (szczególnie przy okazji dwóch kolejnych pielgrzymek) oraz osobiście dobrych kontaktów z Kazimierzem Barcikowskim w czasie obrad Komisji Wspólnej. Szerzej zob. R. Łatka, Obraz opozycji..., s. 43-62. Równocześnie kard. Macharski na posiedzeniu RG 26 czerwca zwracał uwagę na zupełnie inną - negatywną - postawę wojewody nowosądeckiego Lecha Bafii. AAW, SPP, 04/34, Rada Główna Episkopatu Polski 1979, Protokół Rady Głównej Episkopatu Polski z 26 VI 1979, k. 133-134.

${ }^{120}$ Wskazywano na utrudnienia w diecezjach przemyskiej, gdańskiej i lubelskiej. Ibidem, k. 135-136; AAW, SPP, 04/299, Konferencja Plenarna Episkopatu Polski z 5-6 IX 1979, 
przez poszczególne diecezje, by podjąc interwencję u władz centralnych ${ }^{121}$ (niestety w Archiwum Archidiecezji Warszawskiej nie znalazłem tego typu dokumentacji). Wzorowo z tego zadania miała się wywiązać jedynie diecezja przemyska ${ }^{122}$. Arcybiskup Stroba wskazywał, że utrudnienia w terenie nie były przypadkowe i miały zaplanowany charakter oraz jak dodawał: „nie wygląda to na działania jakiejśs frakcji przeciwnej. To było powszechne. Właściwie dziwić się temu za bardzo nie można. Zbyt wiele mieli lęków i stąd szły te ograniczenia" 123 . Istotnymi elementami działania władz, jak wskazywali członkowie RG, były dezinformacja oraz zastraszanie wiernych, wpływające na zmniejszenie frekwencji w czasie niektórych uroczystości czy brak grup pielgrzymów z niektórych regionów kraju, którzy nie dotarli, jak podkreślał kard. Wyszyński, na skutek „dywersji” ${ }^{24}$. Prymas zaznaczył, iż wskutek jego interwencji w prasie codziennej zaczęły się ukazywać informacje na temat pielgrzymki, na ogół utrzymane w pozytywnym tonie ${ }^{125}$. Kardynał Wyszyński w swoim podsumowaniu nieco przekornie wskazywał: „Czy to nie fenomen żeby komuniści stawiali krzyż na Placu Zwycięstwa. Proszę to rozważyć, to jest jakieś osiagnięcie. Przecież ciagle ich zachęcamy, żeby uwierzyli, oni więc na swój sposób uwierzyli, bo wybudowali na Placu Zwycięstwa ten Krzyż"126. Przywódca polskiego Kościoła zwracał również uwagę, iż w czasie rozmowy z przewodniczącym Rady Państwa Henrykiem Jabłońskim postawił sprawę kolejnej pielgrzymki, w 1982 r., na jubileusz 600-lecia Jasnej Góry ${ }^{127}$.

Protokół 170 Konferencji Plenarnej Episkopatu Polski, Warszawa, 5 i 6 IX 1979, k. 74-75; P. Raina, Kardynat Wyszyński. Czasy prymasowskie 1979..., s. 104-105.

${ }^{121}$ AAW, SPP, 04/34, Rada Główna Episkopatu Polski 1979, Protokół Rady Głównej Episkopatu Polski z 26 VI 1979, k. 141-142.

122 Ibidem, k. 142.

${ }^{123}$ Ibidem, k. 138.

124 Ibidem, k. 139-142.

${ }^{125}$ Ibidem, k. 134-135. Warto dodać, iż podobny ton dominował również w czasie kolejnych pielgrzymek papieskich. Szerzej zob. R. Łatka, Wstep..., s. 16-30; idem, Propaganda władz PRL wobec drugiej wizyty Jana Pawła II na przykładzie „Gazety Krakowskiej”, „Komunizm: System - Ludzie - Dokumentacja” 2013, nr 2, s. 95-107.

126 AAW, SPP, 04/34, Rada Główna Episkopatu Polski 1979, Protokół Rady Głównej Episkopatu Polski z 26 VI 1979, k. 131. Jak wspominał prymas Wyszyński w jednym ze swoich przemówień z 1979 r., ten krzyż miał dla niego niezwykle istotne znaczenie: „Krzyż wzniesiony na Placu Zwycięstwa [...] był dla mnie ogromnym przeżyciem. Pamiętam bowiem moje lata szkolne 1912-1915. Idąc do Saskiego Ogrodu często przechodziłem obok ogromnego soboru który był tam ustawiony na polecenie cara, na znak zwycięstwa prawosławia w Warszawie. [...] Gdy 2 czerwca 1979 roku podczas pobytu Ojca Świętego w Polsce siedziałem na Placu Zwycięstwa i wsłuchiwałem się w słowa Papieża, miałem w oczach te dwa krańce polskiej rzeczywistości. [...] Myślałem wtedy o tym, jak potężne muszą być drogi Boże, aby doszło do tego, że Papież Kościoła rzymskokatolickiego sprawuje Najświętszą ofiarę w tym miejscu, gdzie stał ołtarz prawosławnego soboru. Nikt z nas nie mógłby wymyślić tego naprzód”. Cyt. za: Człowiek niezwykłej miary..., s. 115.

${ }^{127}$ AAW, SPP, 04/34, Rada Główna Episkopatu Polski 1979, Protokół Rady Głównej Episkopatu Polski z 26 VI 1979, k. 151. 
Osiagnięcia w dziedzinie politycznej podsumował prymas Wyszyński w materiale przygotowanym na wrześniowe posiedzenie RG, zatytułowanym „Problemy do rozważania przez Radę Główną i Konferencję Plenarną Episkopatu Polski”. Podkreślał w nim, że katolicy uświadomili sobie, że tworza ogromna siłę społeczna, ożywiła się ich świadomość społeczna oraz odzyskali podmiotowość. W kontekście relacji z władzami jako efekty pielgrzymki przywódca polskiego Kościoła wymieniał:

a/ Kościół został uznany przez partię jako konstruktywny partner, jako konstruktywna siła społeczna /Kania/

b/ Kościół okazał się jako siła zorganizowana, mająca posłuch w społeczeństwie, z którą reżym polityczny, partia musi się liczyć i ułożyć stosunki

c/ Ukazane zostało na forum publicznym w opinii krajowej i światowej, że katolikom nie można odmawiać prawa udziału w życiu publicznym i politycznym [...]

d/ Polska została ukazana Zachodowi jak i tzw. Wschodowi, że jest katolicka, że socjalizm nie zapuścił korzeni mimo stworzenia pewnych struktur socjalistycznych, że sprawujący władze są na nawierzchni społeczeństwa i, że w nim nie maja korzeni ${ }^{128}$.

Uzupełnieniem wspomnianego dokumentu była kolejna analiza przygotowana przez prymasa na posiedzenie RG 4 września, zatytułowana „Uwagi i obserwacje po pobycie Ojca św. Jana Pawła II w Polsce"129. Prymas odpowiedział w nim na kluczowe z punktu widzenia efektów pielgrzymki pytanie: kto zyskał więcej - Kościół czy państwo? Odpowiedź przywódcy polskiego Kościoła miała jednoznaczny charakter. Warto ją w tym miejscu przytoczyć in extenso:

1/ Odmawiajac papieżowi prawa wjazdu do swojej Ojczyzny Państwo Ludowe [sic!] na pewno wiele by straciło na opinii krajowej i światowej.

2/ Wyrażając zgodę na przyjazd - Państwo Ludowe na pewno zyskiwało w opinii publicznej - chociaż mogło tracić wśród niektórych kół partyjnych na skutek tak bliskiej konfrontacji Kościół-Państwo [sic!].

3/ Kościół i w pierwszym i w drugim wypadku nic nie straciłby w opinii krajowej i światowej. Na pewno by nie przypisano Kościołowi w Polsce żadnej odpowiedzialności. Co więcej, opinia uznałaby, że Kościół ma rację, gdy w takiej sytuacji stosuje opozycję.

4/ Na pewno Kościół wiele zyskał nie tylko dlatego, że wierni spotkali się z Głowa Kościoła; ale i dlatego, że uznali słuszność Kościoła walczącego o prawa instytucji kościelnych i prawa Wiernych [sic!].

${ }^{128}$ Ibidem, Problemy do rozważania przez Radę Główną i Konferencję Plenarną Episkopatu Polski, 1 IX 1979, Choszczówka, k. 157-158. Podobną ocenę efektów wizyty przedstawił prof. Jan Szczepański, socjolog, doradca Gierka, jak również rozmówca prymasa Wyszyńskiego. Jego analiza znalazła się w dokumentacji RG Episkopatu. Zob. ibidem, J. Szczepański, Po wizycie, 3 VII 1979, k. 205-209.

${ }^{129}$ Ibidem, S. Wyszyński, Uwagi i obserwacje po pobycie Ojca św. Jana Pawła II w Polsce, VIII 1980, k. 242-253. 
5/ Bądź co bądź na Placu Zwycięstwa, pracowicie budowanej naszej Stolicy Państwa Laickiego [sic!] stanął ogromy krzyż z czerwoną stułą Zmartwychwstałego Chrystusa wybudowanego przez państwowych techników. Pozostanie on w oczach Narodu i świata - jako wymowny symbol po 35 latach państwowej walki z religią ${ }^{130}$.

Warto podkreślić, iż prymas spodziewał się, iż w kręgach partyjnych będą poszukiwane nowe, bardziej skomplikowane metody walki z Kościołem, by ograniczyć wzrost jego roli społecznej ${ }^{131}$. Równocześnie jasno stwierdzał, iż duchowieństwo nie może „spocząć na laurach”, ale musi wykorzystać ożywienie religijne społeczeństwa do lepszej pracy ${ }^{132}$. Arcybiskup Stroba z kolei podkreślał:

Trzeci element, który mi przychodzi do głowy, to ten o którym mówił p. Szczepański $^{133}$, że dla Kościoła sytuacja się zmieniła. Wyszliśmy z epoki konfrontacji na pole współpracy. W społeczeństwie świeckim, a równocześnie w społeczeństwie młodym, komunistycznym, powstają ruchy kontestacyjne. Kościół znalazł się w środku między partią a tą kontestacją najbardziej lewicową. I tu może być niebezpieczeństwo wmanewrowania Kościoła na pozycję współpracy z partią rządząca. A z pozycją współpracy wiąze się instrumentalizacja. Etap jest nowy, są więc nowe szanse po temu. Stąd czujność, wrażliwość, analiza pod tym względem byłaby niebywale ważna ${ }^{134}$.

Prymas uwagi metropolity poznańskiego potraktował jako zbyt kategoryczne, wskazujacc, iż z ryzykiem instrumentalizacji Kościół borykał się od porozumienia z 1950 r. Podkreślał równocześnie, że argumentem biskupów w rozmowach z władzami jest wizyta Jana Pawła II i jej przebieg, zauważał również niekonsekwencje dygnitarzy partyjnych, pytając retorycznie: „Panowie, kiedy więc kłamiecie? Czy wtedy kiedy był Papież, i wyrażaliście zadowolenie z jego wizyty, czy teraz? Czy teraz, zaczynacie na nowo i chcecie odrodzić, to coście przegrali jako etap stabilizacji, a później destabilizacji” ${ }^{135}$.

${ }^{130}$ Ibidem, k. 247-248. Równocześnie prymas dodawał, iż jednoznacznie podniósł się prestiż państwa polskiego. Ibidem, k. 248. Por. z oceną sporządzoną na potrzeby KC PZPR: Wstępna ocena przebiegu wizyty Jana Pawła II, zachowań społecznych i treści przemówień papieża opracowana w Wydziale Pracy Ideowo-Wychowawczej KC PZPR w czerwcu 1979 r., w: Wizyta Jana Pawła II..., s. 270.

131 Prymas miał rację, wskazując, iż władze będą poszukiwać nowych metod walki z Kościołem. Szerzej zob. Dokument przedstawiający program przeciwdziałania negatywnym dla ustroju skutkom pielgrzymki Jana Pawła II, opracowany zapewne w Wydziale Pracy Ideowo-Wychowawczej KC PZPR, [b.d.], w: Wizyta Jana Pawta II..., s. 300-316.

${ }^{132}$ AAW, SPP, 04/34, Rada Główna Episkopatu Polski 1979, S. Wyszyński, Uwagi i obserwacje po pobycie Ojca św. Jana Pawła II w Polsce, VIII 1980, k. 250-251. Arcybiskup Stroba podkreślał, żeby na relacje państwo-Kościół nie patrzeć przez pryzmat pielgrzymki, ale oceniać je całościowo na podstawie poprzednich lat. Ibidem, Protokół Rady Głównej Episkopatu Polski z 4 IX 1983, k. 265.

${ }^{133}$ Chodzi o analize „Po wizycie”: ibidem, J. Szczepański, Po wizycie, 3 VII 1979, k. 205-209.

134 AAW, SPP, 04/ 34, Rada Główna Episkopatu Polski, Protokół Rady Głównej Episkopatu Polski z 4 IX 1979, k. 266-267.

${ }^{135}$ Ibidem, k. 268. 
Kardynał Wyszyński zdecydowanie dodawał, patrząc przez pryzmat nabożeństw z udziałem Ojca Świętego, iż władze nie maja prawa ingerować w religijność Narodu oraz że czyniąc to, niczego nie osiagna ${ }^{136}$. W trakcie posiedzenia prymas wskazywał, iż zgodnie z wolą Jana Pawła II należy dążyć do normalizacji relacji z władzami ${ }^{137}$. Swoje spojrzenie na tę kwestię uzupełnił $\mathrm{w}$ materiałach przygotowanych na kolejne, październikowe posiedzenie $\mathrm{RG}^{138}$. Kierował się pod tym względem wskazaniem polskiego papieża z czerwcowej Rady, iż z inicjatywą normalizacji należy wyczekiwać, aż władzom tak będzie na tym zależeć, że przyjmą wszystkie warunki Kościoła ${ }^{139}$.

Istotny efekt wizyty Jana Pawła II stanowiło w przekonaniu członków RG ożywienie religijne, nie tylko zresztą w Polsce, ale we wszystkich właściwie państwach bloku wschodniego ${ }^{140}$. Jak zauważył bp Tokarczuk, papież nadał nowy wymiar polityce wschodniej ${ }^{141}$. Biskup Dąbrowski wskazywał na pogłębienie wiary wśród młodzieży ${ }^{142}$. Najlepiej międzynarodowe znaczenie pielgrzymki Ojca Świętego oddał ordynariusz przemyski, który podkreślił:

${ }^{136}$ Ibidem, k. 268. Prymas ponadto przewidywał, że „Wzrost nadziei na przezwyciężenie tępej laicyzacji i ateizacji politycznej, na to, że bramy piekielne nie przezwyciężą porządku ewangelicznego Kościoła”, zapis z 9 VI 1979, cyt. za: E.K. Czaczkowska, op. cit., s. 650. Zob. też: P. Raina, Kardynat Wyszyński. Czasy prymasowskie 1979..., s. 128-129.

${ }^{137}$ AAW, SPP, 04/ 34, Rada Główna Episkopatu Polski, Protokół Rady Głównej Episkopatu Polski z 4 IX 1979, k. 265-281. RG Episkopatu wysłała również w tej sprawie list do Jana Pawła II, deklarując jednoznacznie wolę normalizacji stosunków z władzami. Ibidem, Pismo Rady Głównej Episkopatu Polski do Jana Pawła II z 11 X 1979, k. 300-301. Prymas Wyszyński stawiał tę sprawę jednoznacznie również czasie konferencji biskupów ordynariuszów 5 września. AAW, SPP, 04/299, Konferencja Plenarna Episkopatu Polski z 5-6 IX 1979, Protokół z konferencji księży biskupów ordynariuszów dnia 5 IX 1979, k. 69-70.

138 AAW, SPP, 04/34, Rada Główna Episkopatu Polski, S. Wyszyński, Problemy do rozważenia na posiedzeniu Rady Głównej w dniu 11 października 1979, Warszawa, 10 X 1979, k. 292-299.

139 Ibidem, k. 292-293. Szczegółowo swoją koncepcję normalizacji relacji państwo-Kościół prymas przedstawił w czasie obrad Konferencji Plenarnej Episkopatu 5 IX 1979 r. AAW, SPP, 04/299, Konferencja Plenarna Episkopatu Polski z 5-6 IX 1979, Protokół 170 Konferencji Plenarnej Episkopatu Polski, Warszawa, 5 i 6 IX 1979, k. 76-77.

140 AAW, SPP, 04/34, Rada Główna Episkopatu Polski 1979, Protokół Rady Głównej Episkopatu Polski z 26 VI 1979, k. 142-149; ibidem, Problemy do rozważania przez Radę Główną i Konferencję Plenarną Episkopatu Polski, 2 IX 1979, Choszczówka, k. 157; ibidem, Protokół Rady Głównej Episkopatu Polski z 4 IX 1983, k. 263-264.

${ }^{141}$ Ibidem, Protokół Rady Głównej Episkopatu Polski z 26 VI 1979, k. 146. Por. z ocena sporządzoną na potrzeby KC PZPR: Wstępna ocena przebiegu wizyty Jana Pawła II, zachowań społecznych i treści przemówień papieża opracowana w Wydziale Pracy Ideowo-Wychowawczej KC PZPR w czerwcu 1979 r., w: Wizyta Jana Pawła II..., s. 264-265.

142 AAW, SPP, 04/34, Rada Główna Episkopatu Polski 1979, Protokół Rady Głównej Episkopatu Polski z 26 VI 1979, k. 148. Z tego względu po pielgrzymce MSW postanowiło podjaćc działania zmierzające do zmniejszenia wpływu Kościoła na młodzież. Sprawozdanie z działań Ministerstwa Spraw Wewnętrznych związanych z pobytem w Polsce Jana Pawła II, w: Wizyta Jana Pawta II..., s. 297. 
Gdy chodzi o wymiar międzynarodowy to opinia światowa widzi dzisiaj w Kościele i w Ojcu Świętym przywódcę międzynarodowego. Stąd pochodzi odrodzenie religijno-moralne. Świat odkrywa na nowo, że najpotężniejszą siłą społeczną jest Kościół, jest religia. I zaczyna się o tej religii mówić w kręgach, gdzie był inny klimat, o religii, bardzo pozytywnie, ze zrozumieniem, o jej roli i znaczeniu. Mówi się, że nie ma wielkich przywódców, bo nie ma wielkich idei. W związku z tym Kościół staje się dzisiaj największym obrońcom [sic!] praw człowieka w sensie uniwersalnym, nie tylko praw politycznych, społecznych, ale wolności sumienia, prawa do wyznawania religii, swoich osobistych przekonan ${ }^{143}$.

Innym z międzynarodowych efektów wizyty papieża w Ojczyźnie - zdaniem kard. Wyszyńskiego - było przełamanie przez Jana Pawła II bariery żelaznej kurtyny. W jego przekonaniu upadł tym samym dogmat o przymusowej ateizacji w krajach komunistycznych ${ }^{144}$, państwa w bloku powinny przemyśleć swój stosunek do religii. Prymas dostrzegł także zaniepokojenie Związku Sowieckiego związane ze wzrostem nadziei na wolność religijną na Litwie, Łotwie, Estonii, Białorusi czy Ukrainie. Podkreślał, że papiė̇ stał się „niebezpieczny” dla całego bloku wschodniego ${ }^{145}$.

W czasie kolejnych posiedzeń RG w 1979 r., 11 października ${ }^{146}$ i 14 listopada $^{147}$, wątku pielgrzymki papieskiej i jej efektów nie poruszano. Decyzja Rady zamierzano wrócić do tej problematyki w czasie grudniowej sesji ${ }^{148}$, mimo to w czasie jej trwania tematyki tej nie omawiano ${ }^{149}$.

${ }^{143}$ AAW, SPP, 04/34, Rada Główna Episkopatu Polski 1979, Protokół Rady Głównej Episkopatu Polski z 26 VI 1979, k. 146-147.

144 Jak pisał prymas: „mur dzielący Europę na dwa światy” został nadwyrężony, zapis prymasa z 9 VI 1979, za: E.K. Czaczkowska, op. cit., s. 650. Analogiczny wniosek wyciagną kard. Macharski. AAW, SPP, 04/34, Rada Główna Episkopatu Polski 1979, Protokół Rady Głównej Episkopatu Polski z 4 IX 1983, k. 264.

145 Ibidem, S. Wyszyński, Uwagi i obserwacje po pobycie Ojca św. Jana Pawła II w Polsce, VIII 1980, k. 249. Por. z oceną sporządzoną na potrzeby KC PZPR: Wstępna ocena przebiegu wizyty Jana Pawła II, zachowań społecznych i treści przemówień papieża opracowana w Wydziale Pracy Ideowo-Wychowawczej KC PZPR w czerwcu 1979 r., w: Wizyta Jana Pawta II..., s. 264-265.

146 AAW, SPP, 04/34, Rada Główna Episkopatu Polski 1979, Protokół Rady Głównej Episkopatu Polski z 11 X 1979, k. 302-313; P. Raina, Kardynat Wyszyński. Czasy prymasowskie $1979 \ldots$, s. 135.

${ }^{147}$ AAW, SPP, 04/34, Rada Główna Episkopatu Polski 1979, Protokół Rady Głównej Episkopatu Polski z 14 XI 1979, k. 334-343.

148 Ibidem, k. 337.

149 Ibidem, Protokół Rady Głównej Episkopatu Polski z 12 XII 1979, k. 362-391; P. Raina, Kardynat Wyszyński. Czasy prymasowskie 1979..., s. 168-169. W dokumentacji kościelnej ocena wizyty pojawia się jeszcze w analizie „Kościół a państwo”, sporządzonej przez prymasa Wyszyńskiego, ale nie ma w niej nowych istotnych wątków, które należałoby osobno omówić. AAW, SPP, Kościół a państwo 1976-1980, S. Wyszyński, Kościół a państwo, 28 X 1979. 


\section{Podsumowanie}

Dokumentacja RG Episkopatu Polski w istotny sposób uzupełnia spojrzenie historyka na pierwszą pielgrzymkę Jana Pawła II do Ojczyzny. Dzięki tym materiałom możemy zapoznać się $\mathrm{z}$ negocjacjami zwiąanymi $\mathrm{z}$ terminem pielgrzymki, przebiegiem przygotowań kościelnych, ustaleniem ostatecznego kształtu jej programu i wreszcie jej efektów z perspektywy najważniejszych polskich hierarchów, którzy kierowali w omawianym okresie polskim Kościołem. Kluczowe pod tym względem są protokoły RG, które pokazują m.in., jak kształtowało się stanowisko negocjacyjne polskich biskupów, jakie alternatywne terminy przyjazdu Ojca Świętego były rozpatrywane przez prymasa Wyszyńskiego i jego współpracowników oraz dlaczego zgodzono się na ustępstwa wobec władz w kilku szczegółowych elementach programu pobytu papieża. Ponadto ukazuja mechanizmy podejmowania decyzji w Kościele katolickim $\mathrm{w}$ związku z pielgrzymka, a szerzej patrząc, w jego relacjach i konfrontacji z władzami Polski „ludowej”. Ich analiza pozwala na wyciagnięcie wniosku, że to właśnie w RG zapadały kluczowe dla programu wizyty Jana Pawła II decyzje strony kościelnej, zaś Konferencja Plenarna Episkopatu miała tu znaczenie pomocnicze i była pozbawiona wpływu na najważniejsze kwestie związane z pielgrzymka. Pokazują również rzeczywistą hierarchię wśród polskich biskupów, nad którymi niepodzielnie panował prymas Wyszyński. Jego najdalej idacym zaufaniem cieszył się bp Dąbrowski, którego pozycja również była niepodważalna, przede wszystkim ze względu na sprawne prowadzenie relacji z władzami państwowymi, w tym negocjacji związanych z pielgrzymka Jana Pawła II do Ojczyzny. Ponadto da się zauważyć, iż bardzo szybko jednym z najważniejszych polskich hierarchów stał się abp Macharski, cieszący się zaufaniem Ojca Świętego i pełniący funkcje wiceprzewodniczącego Episkopatu (to właśnie on zastępował chorego prymasa w prowadzeniu posiedzenia RG 3 V 1979). W podsumowaniu wspomnieć należy również o przebiegu posiedzenia RG 5 czerwca z udziałem Jana Pawła II, które wyznaczyło kierunek działalności Kościoła po pielgrzymce oraz pokazywało, iż polski papież ma ogromne zaufanie do członków RG, konsultując z nimi decyzje dotyczące nie tylko roli Kościoła w Polsce, ale również sposobu funkcjonowania Stolicy Apostolskiej.

\section{Streszczenie}

Pierwsza wizyta Jana Pawła II w Ojczyźnie to niewątpliwie z wielu powodów wydarzenie o charakterze przełomowym w dziejach Polski. W swojej analizie omówiłem przygotowania, przebieg oraz efekty przyjazdu Jana Pawła II do Ojczyzny przez pryzmat opinii Rady Głównej Episkopatu, czyli gremium decyzyjnego w polskim Kościele. Stało się to możliwe dzięki dostępowi do materiałów Sekretariatu Prymasa Polski pochodzących ze zbiorów Archiwum Archidiecezji Warszawskiej. Spojrzenie na tę problematykę przez pryzmat ciała kluczowego 
i decyzyjnego w polskim Kościele w istotny sposób uzupełni stan dotychczasowych badań o nowe wątki. Dzięki wspomnianym materiałom możemy zapoznać się z negocjacjami związanymi z terminem pielgrzymki, przebiegiem przygotowań kościelnych, ustaleniem ostatecznego kształtu jej programu i wreszcie jej efektami z perspektywy najważniejszych polskich hierarchów, którzy kierowali w omawianym okresie polskim Kościołem. Ich analiza pokazuje nie tylko stosunek Rady Głównej do pielgrzymki, ale również rzeczywistą hierarchię wśród polskich biskupów. Wspomnieć należy także o przebiegu posiedzenia Rady Głównej 5 VI 1979 r. z udziałem Jana Pawła II, które pokazywało, iż polski papież ma ogromne zaufanie do członków Rady, konsultując z nimi nawet decyzje sposobu funkcjonowania Stolicy Apostolskiej.

\section{The Main Council of the Polish Episcopate and Pope John Paul II's first pilgrimage to Poland in 1979}

The first visit of Pope John Paul II to Poland was, for many reasons, a momentous event in the history of Poland. In my analysis I have discussed the preparations, course and outcomes of Pope John II's visit to Poland seen from the perspective of the Main Council of the Polish Episcopate, that is the authorities of the Polish Church. This has been made possible thanks to the access to documents of the Secretariat of the Primate of Poland kept in the Archives of the Warsaw Archdiocese. Looking at the problem through the prism of the most important decisive body of the Polish Church will make an important contribution to the present state of research. The materials give us the insight into negotiations over the dates of the pope's visit, the preparations of the Church, establishment of the final form of its schedule, and finally, its outcomes as seen through the eyes of the most important Polish Church hierarchs. An analysis of the archival documents makes it possible to conclude that it was the Main Council of the Polish Episcopate that made decisions fundamental importance for the schedule of Pope John Paul II's first visit to Poland, while the Polish Episcopal Conference was of secondary importance here and was without the real influence on the most important questions related to the pope's pilgrimage. The documents also reveals the actual hierarchy of the Polish bishops under Primate Stefan Wyszyński. It should be mentioned here that the Main Council session of 5 June 1979 attended by Pope John Paul II set the line of the Church in Poland after the pope's visit and showed that the Polish pope had trust in the Council and consulted with them his decisions not only on the role of the Church in Poland but also some aspects of the Apostolic See.

\section{Bibliografia}

Czaczkowska E.K., Kardynat Wyszyński. Biografia, Kraków 2013.

Człowiek niezwyktej miary. Ojciec Święty Jan Pawet II o kardynale Stefanie Wyszyńskim. Kardynat Stefan Wyszyński o sobie. Kardynat Józef Glemp o kardynale Stefanie Wyszyńskim, red. M. Plaskacz, A. Rastawicka, W. Wojdecki, Warszawa 1984.

Dudek A., Gryz R., Komuniści i Kościót w Polsce (1945-1989), Kraków 2006.

Dudek A., Ślady PeeRelu. Ludzie, wydarzenia, mechanizmy, Kraków 2005.

Friszke A., PRL wobec Kościoła. Akta Urzędu do Spraw Wyznań 1970-1978, Warszawa 2010.

Friszke A., Zaremba M., Wokót pierwszej pielgrzymki, w: Wizyta Jana Pawła II w Polsce 1979. Dokumenty KC PZPR i MSW, oprac. A. Friszke, M. Zaremba, Warszawa 2005, s. 6-81. Gryz R., Między liberalizacja a dezintegracja. Stosunki państwo-Kościót w latach siedemdziesiatych, w: Stosunki państwo-Kościół w Polsce w latach 1944-2010. Studia i materiaty, red. R. Łatka, Kraków 2013, s. 72-91. 
Kąkol K., Spowiedź pogromcy Kościoła, Olsztyn 1994.

Kindziuk M., Kardynat Józef Glemp. Ostatni taki prymas, Warszawa 2010.

Kościót w PRL. Kościót katolicki a państwo w świetle dokumentów 1945-1989, t. III: Lata 1975-1989, oprac. P. Raina, Poznań-Pelplin 1996.

Lasota M., Zabezpieczenie pobytu Jana Pawła II w Polsce, w: Operacja: zniszczyć Kościót, red. F. Musiał, J. Szarek, Kraków 2007, s. 135-159.

Łatka R., Droga do ustawowego uregulowania osobowości prawnej Kościoła katolickiego w Polsce „ludowej”, „Colloquium Wydziału Nauk Humanistycznych i Społecznych” 2015, nr 4.

Łatka R., Obraz opozycji w czasie rozmów Komisji Wspólnej Przedstawicieli Rzqdu PRL $i$ Episkopatu Polski $w$ latach 1980-1983, w: Miejsce i rola opozycji w systemach autorytarnych i demokratycznych, red. K. Kowalik, M. Kluzik, Kraków 2013, s. 43-62.

Łatka R., Polityka władz Polski „ludowej” wobec Kościoła katolickiego w latach 1944-1979 (przypadek krakowski), „Zeszyty Historyczne WiN-u” 2014, nr 39, s. 169-188.

Łatka R., Polityka władz PRL wobec Kościoła katolickiego w województwie krakowskim w latach 1975-1980, w: PRL na pochylni 1975-1980, red. M. Bukała, D. Iwaneczko, Rzeszów 2017, s. 691-722.

Łatka R., Polityka władz PRL wobec Kościoła katolickiego w województwie krakowskim w latach 1980-1989, Kraków 2016.

Łatka R., Propaganda władz PRL wobec drugiej wizyty Jana Pawła II na przyktadzie „Gazety Krakowskiej”, „Komunizm: System - Ludzie - Dokumentacja” 2013, nr 2, s. 95-107.

Michalski K., Działalność Komisji Wspólnej przedstawicieli Rzqdu PRL i Episkopatu Polski 1980-1989, Warszawa 2012.

Musiał F., Operacja „Lato-79”. Zadania Stużby Bezpieczeństwa w czasie pierwszej pielgrzymki Jana Pawła II do Polski, „Zeszyty Historyczne WiN-u” 2012, nr 35, s. 219-228.

Nowak A., Czas walki z Bogiem, seria: „Kościół na straży polskiej wolności”, t. IV, Kraków 2011.

Nie można zdradzić Ewangelii. Rozmowy z abp. Ignacym Tokarczukiem, oprac. M. Krzysztofiński, Rzeszów-Kraków 2013.

Piasecki B., Zając M., Prymas Wyszyński nieznany. Ojciec duchowy widziany z bliska, Kraków 2016.

Raina P., 1978. Wybór Papieża Jana Pawła II. Zapiski prymasa, Warszawa 2008.

Raina P., Arcybiskup Dabrowski - rozmowy watykańskie, Warszawa 2001.

Raina P., Arcybiskup Dąbrowski w stużbie Kościoła i Narodu. Rozmowy z władzami PRL, t. I: 1970-1981, Warszawa 1995.

Raina P., Kardynat Wyszyński. Czasy prymasowskie 1978, Biała Podlaska-Warszawa 2010.

Raina P., Kardynat Wyszyński. Czasy prymasowskie 1979, Biała Podlaska-Warszawa 2010.

Raina P., Wizyty apostolskie Jana Pawta II w Polsce. Rozmowy przygotowawcze Watykan-PRL-Episkopat, Warszawa 1997.

Rakowski M.F., Dzienniki polityczne 1979-1981, Warszawa 2004.

W cieniu Prymasa Tysiaclecia. Z profesorem Romualdem Kukotowiczem rozmawia Piotr Baczek, Warszawa 2001.

Weigel G., Świadek nadziei. Biografia papieża Jana Pawła II, tłum. M. Tarnowska i in., Kraków 2012.

Zaremba M., Zimno, ciepło, gorqco. Nastroje Polaków od „zimy stulecia” do lata 1980, w: Solidarność od wewnatrz 1980-1981, red. A. Friszke, K. Persak, P. Sowiński, Warszawa 2013, s. 11-38.

Zieliński Z., współudz. S. Bober, Kościót w Polsce 1944-2007, Poznań 2009.

Żaryn J., Dzieje Kościoła katolickiego w Polsce (1944-1989), Warszawa 2003.

Żaryn J., Jan Pawet II pogromca żelazne kurtyny, w: Solidarność z błoń. Wokót nauczania społecznego Jana Pawła II, red. M. Drzonek, M. Siedziako, Szczecin 2011, s. 15-23. 
Biogram: Rafal Latka - dr nauk społecznych z zakresu nauk o polityce (specjalność historia najnowsza Polski), historyk i politolog, pracownik Biura Badań Historycznych IPN, koordynator Centralnego Projektu Badawczego IPN: „Władze komunistyczne wobec Kościołów i związków wyznaniowych w Polsce 1944-1989”, redaktor naukowy serii wydawniczej: „Kościół katolicki w dokumentach”. Autor, współautor i redaktor 12 książek. Sekretarz redakcji czasopisma „Pamięć i Sprawiedliwość”, członek redakcji pism „Glaukopis” i „Myśl.PL”. E-mail: rafal.latka@ipn.gov.pl. 